\title{
KINDS OF DEFECTS THAT MAKE THE ARCHITECTURE RESPONSIBILITY
}

\author{
Moustafa Rateb Hassan \\ A lecturer of Civil Law Faculty of Low-Assiut University
}

(Received August 24, 2010 Accepted October 20, 2010)

May be a defect in the process of building and construction due to take into account non-chronological order between the various processes, consisting of the building, or origin other stable, so that did not take this process from all operations fortunate enough time to be dry and complete durability, and strengthens its cohesion, so as to be capable of carrying by the following stages.

It may not be caused by the dissolution of the Association, to be due to a defect in the process of construction itself, but due to a defect in the same materials, used in this process were to be damaged as a result of moisture or analyzed to Contents or reused, going so characteristic coherence between her Parts, or be the class of pink is not fit to perform their intended purpose of the strain parts of the construction To each other, tightening the link, and cohesion As it does not matter in the dissolution of this association to be due to a defect in the process of construction and the building itself or due to a defect in the same material used in this process, so is the case whether this decay in the bond that links between parts of the building or origin other stable to be invalid in whole or in part because of the nature of the training or for any reason to build on it, or the establishment of other facilities, provided that the defect of this land, which can be detected according to the rules of art.

If not possible to detect a defect bidder, in accordance with these rules, that were such a force Employer shall not be responsible for Eng.

This has taken care of all legislators, the Egyptian and French, to the disclosure of Opinions in the applicability of the provisions of this responsibility even if it was badly damaged kidneys or in part, that occurred in the construction or origin other stable, due essentially to a defect in the same land, by providing explicit in each of the articles 621 civilian Egypt 0.1972 French civilian, as required by each application should be appropriate, even if badly damaged due to a defect caused by the earth itself.

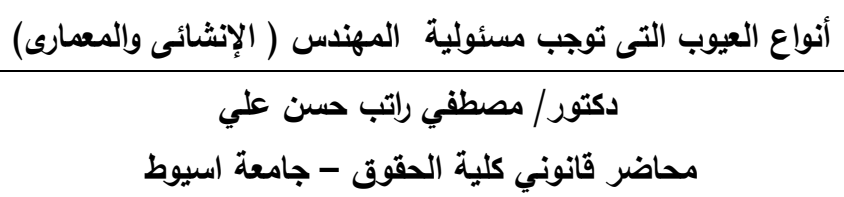




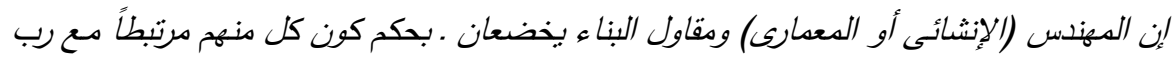

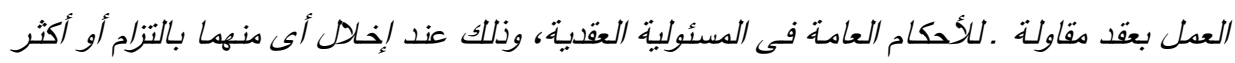

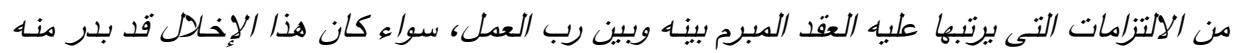

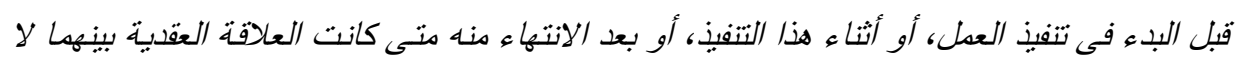

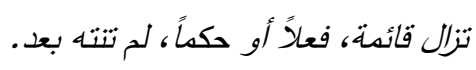

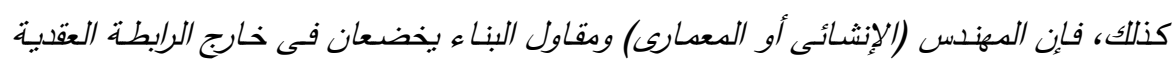

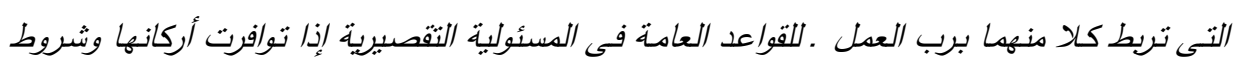

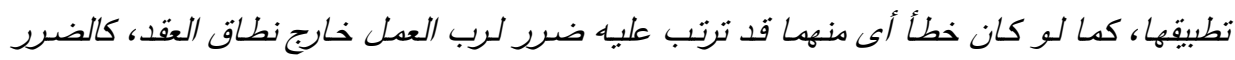

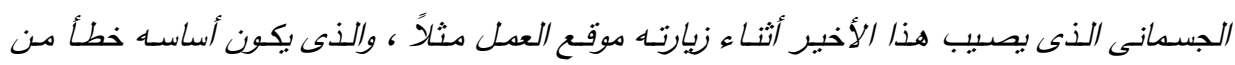

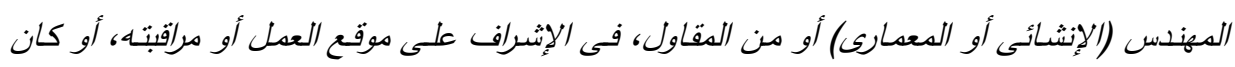

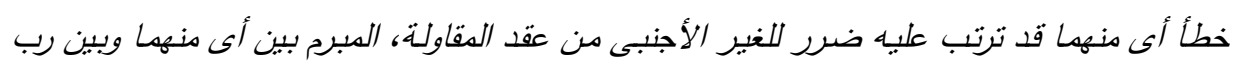

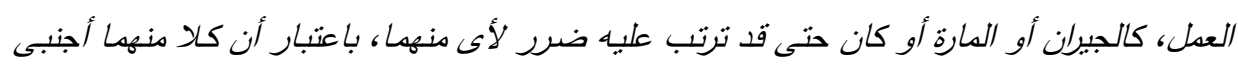
عن الآخر، لانعدام الرابطة العقدية بيئهما.

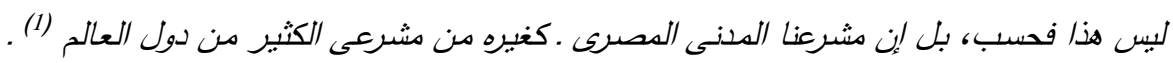

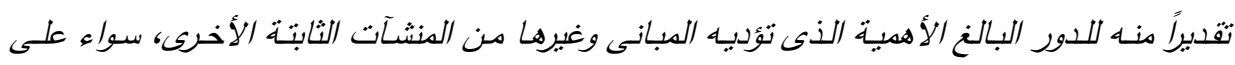

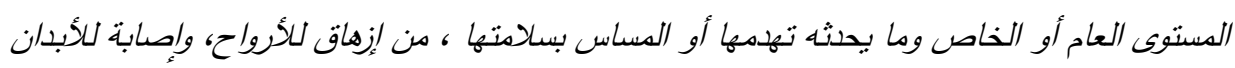

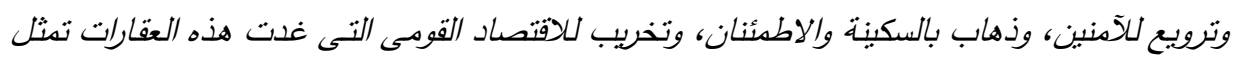

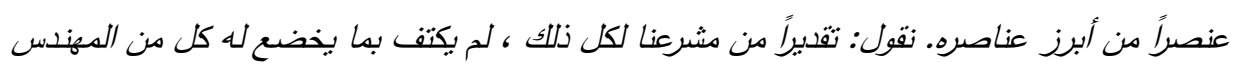

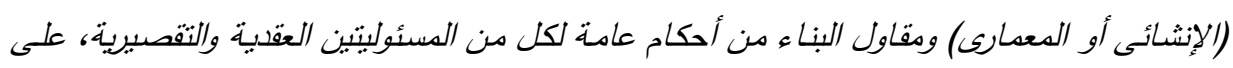

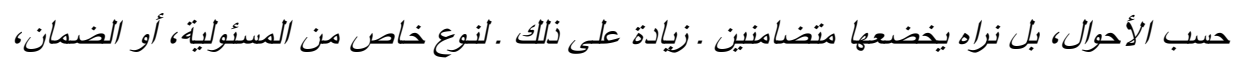

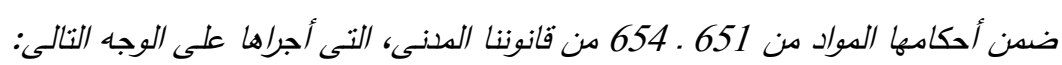

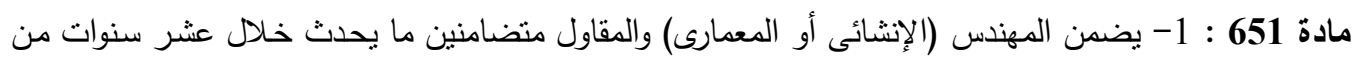

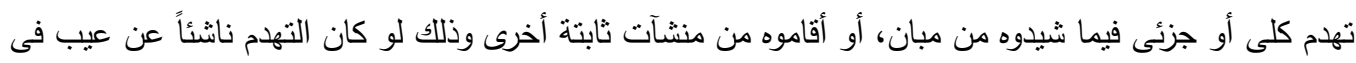

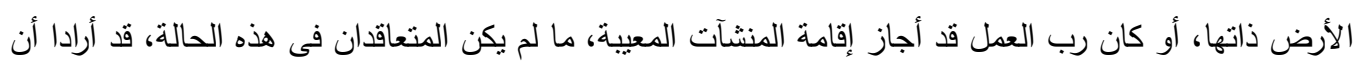
تنقى هذه المنشآت مدة أقل من عشر سنوات. 2- ويشمل الضمان المنصوص عليه فى الفقرة السابقة ما يوجد فى المبانى والمنشآت من عيوب يترتب عليها تهديد متانة البناء وسلامته. 3- وتندأ مدة السنوات العشر من وقت تشليم العمل.

4- ولا تسرى هذه المادة على ما قد يكون للمقاول من حق الرجوع لعنى على الدقاولين من الباطن.

(1) انظر مجموعة الأعمال التحضيرية للقانون المدنى المصرى، ج5، ص21 وما بعدها. 
مادة 652 : إذا اقتصر المهنس (الإنشائى أو المعمارى) على وضع التصميم دون أن يكلف الرقابة على التنفيذ لم يكن مسئولاً إلا عن العيوب التى أنت من التصني التصميم. مـادة 653 : يكون باطلاً كل شرط يقصد بـه إعفاء المهندس (الإنشائى أو المعمارى) والمقاول من الضمان أو الحد منه. مادة 654 : تسقط دعاوى الضمان المتقدمة بانقضاء ثلاث سنوات من وقت حصول التهدم أو انكثاف العيب.

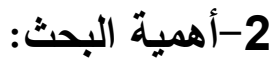

هذا النطور فى الكم والكيف، والامتداد الأفقى والرأسى، فى مجال التشييد والبناء، وما أصبحت تثنله قيمة ما

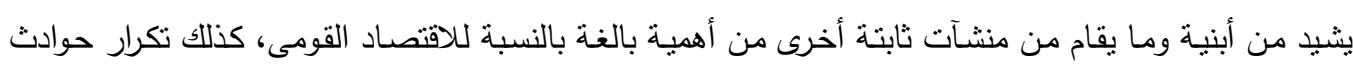

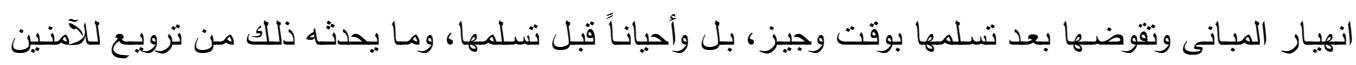

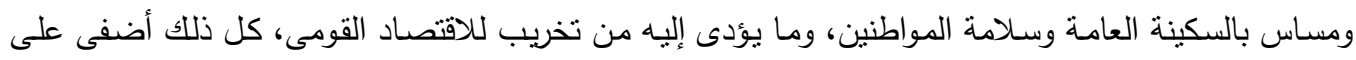

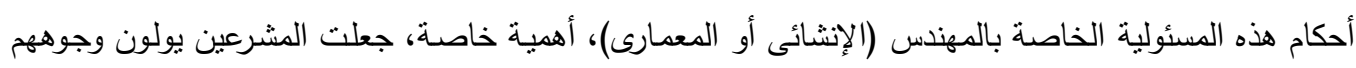

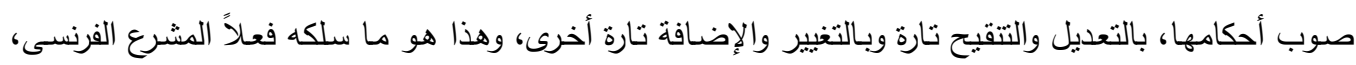

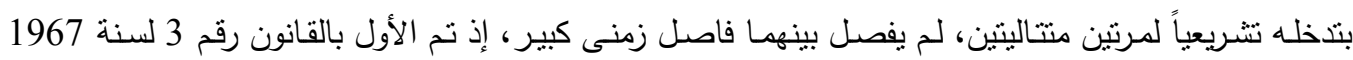
والثانى بالقانون رقم 12 لسنة 1978.

وبذلك غدا كل معمارى فى فرنسا (1) يقوم بتشييد عمل مسئولاً عما يحدث في هذا العمل من أضرار، طبقاً

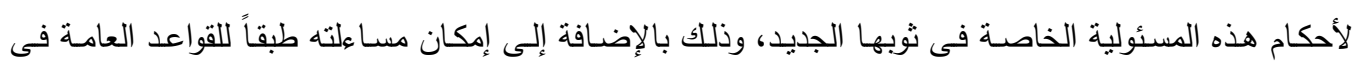
المسئولية العقدية، أو التقصبرية على حسب الأحوال، إذا تحقق سبب ألى منهما.

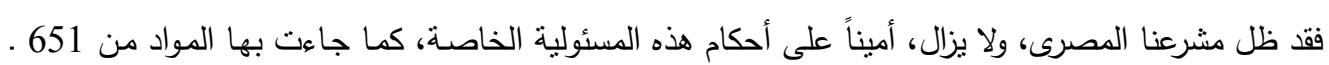

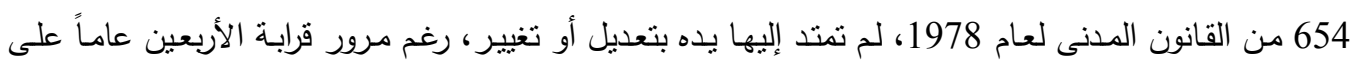

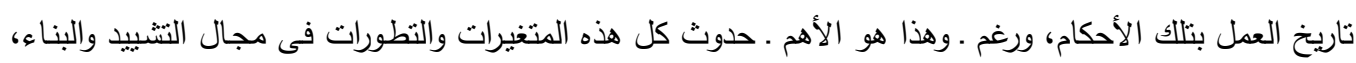

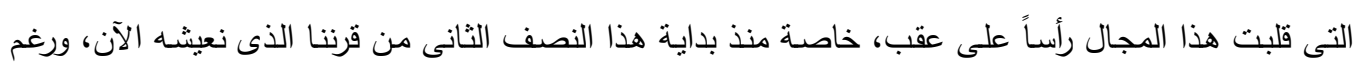

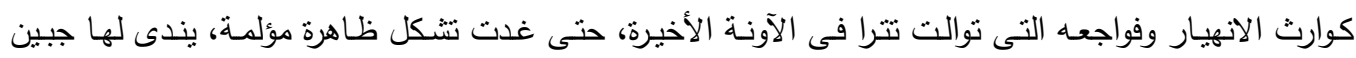

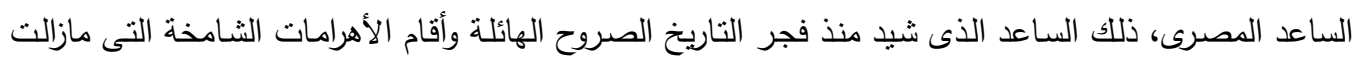

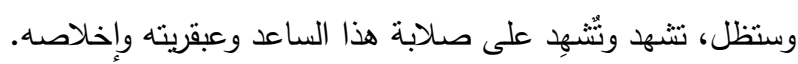

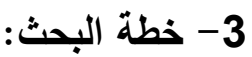

سنتاول هذا البحث من خلال مبحثين وهما : 1-3 مبحث أول: ماهية العيوب الموجبة لقيام المهندس ( الإنثائى أو المعمارى ).

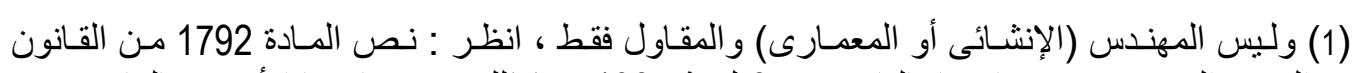

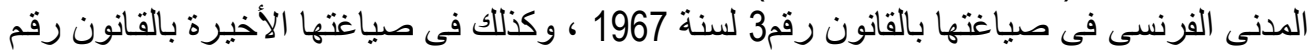

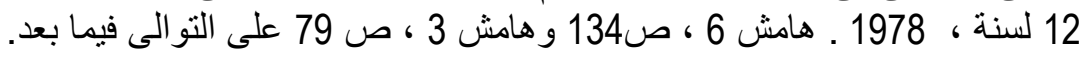




$$
\text { 3-1-1-3 المطلب الأول: تعريف العيب المعمارى. }
$$

3-1-2-3 المطلب الثانى: تعريف المهندس (الإنثائى أو المعمارى) ودوره فى عملية التتبيد.

3-3 مبحث ثانى: أنواع العيوب التى توجب مسئولية المهنس (الإنثائى أو المعمارى).

3-2-1-2 المطلب الأول: العيب الناشئ عن فحص التربة.

3-2-2-2-3 المطلب الثانى: العيب الناشئ عن خطأ في التصميم.

3-2-3-3 المطلب الثالث: العيب الناشئ عن المواد المستعملة فى النتييد.

3-2-4 المطلب الرابع: العيب النانشئ عن خطأ فى التتفيذ.

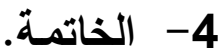

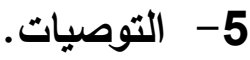

3-1-3 المبحث الأول: ماهية العيوب الموجبة لقيام مسئولية المهنس (الإنثائى أو المعمارى).

1-1-3 المطلب الأول : تعريف العيب المعمارى .

تعريف العيب : يعرف العيب بصفة عامة بأنه " الآفة الطارئة التى تخلو منها الفطرة السليمة للمبيع " (1) .

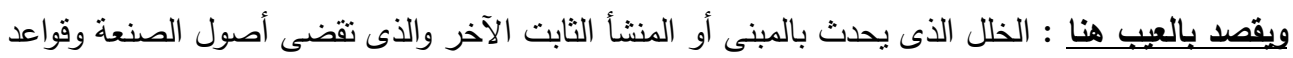

الفن خلوه منه. (2) - (2)

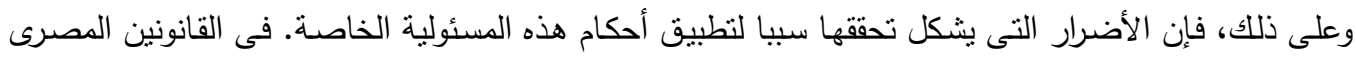

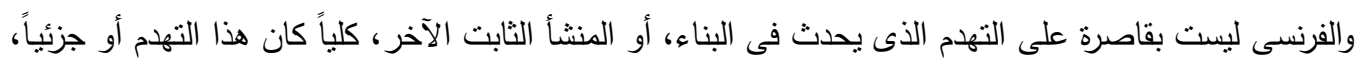

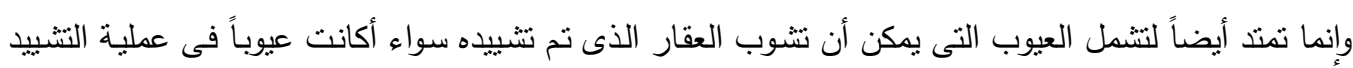

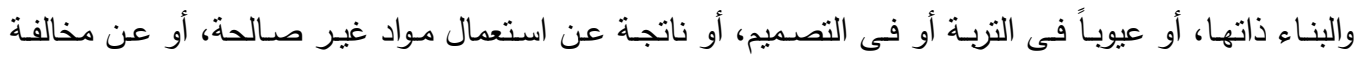
القوانين واللوائح.

وإذا كان المشرع المصرى قد نص صراحة . كما سبق أن أشرنا حالاً . على اعتبار العيوب من موجبات تطبيق

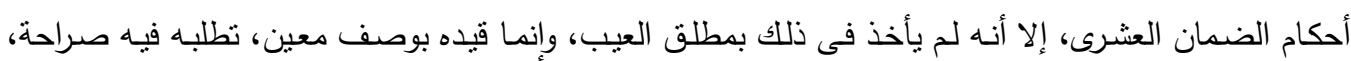

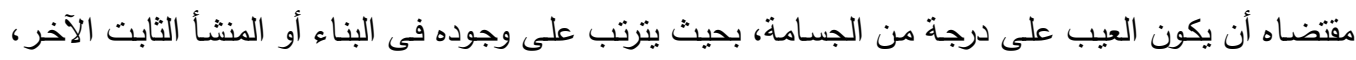
تهديد لمتانته وسلامته.( م 2/651 مدنى).

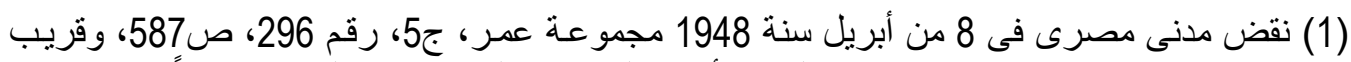

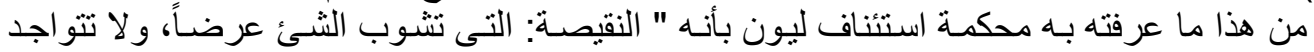

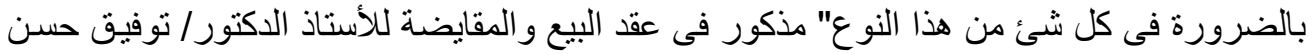

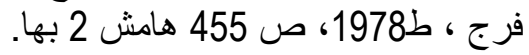
(2) فى نفس المعنى : ياقوت ( محمد ناجى): مسئولية المعماريين بعد إتمام الأعمال وتسلمها مقبولة من رب العمل، ط1، دار النهضة العربية ، 1984. 
كذلك، فإن الفقه والقضـاء المصريين، يضيفان على هذا الثـرط التشريعى شرطاً آخر ، بستوحيانه من القواعد

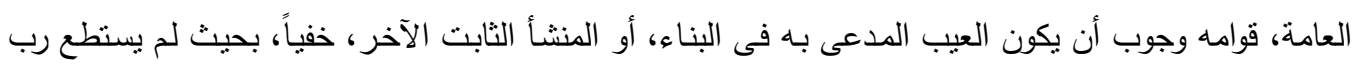

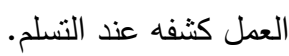

2-1-3 المطلب الثانى : تعريف المهندس (الإنثائى و المعمارى) ودوره فى عملية التثيييا 1-2-1-3 يقصد بالمهندس المدنى: هو مهنس إنثائى يعنى المسئول عن إنشاء الهيكل وتتفيذه ودراسته ،

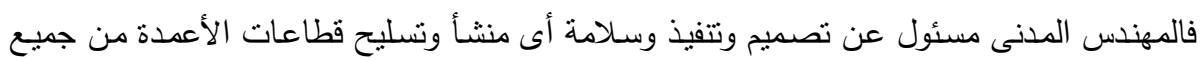

$$
\text { النواحى. }
$$

2-2-3 يقصد بالمهنس المعمارى : ذللك الثخص الحاصل على مؤهل هنسى فى هندسة المعمار ، يؤهله

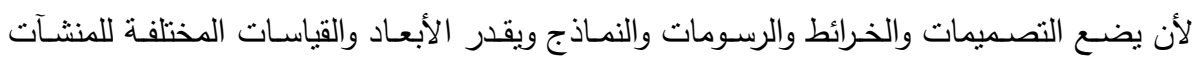

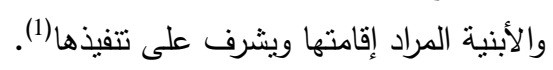

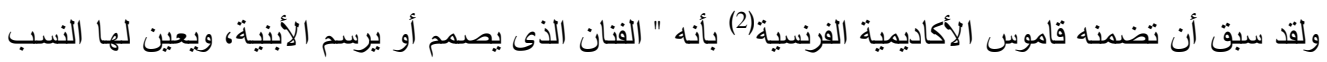

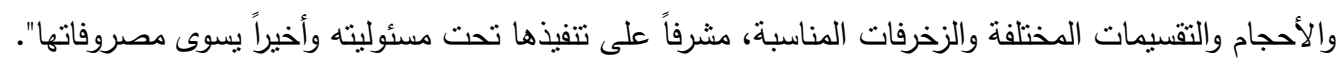

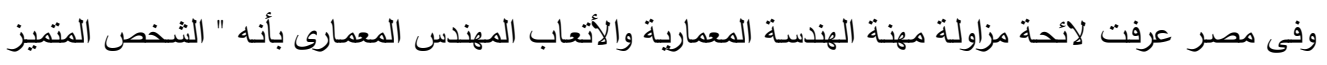

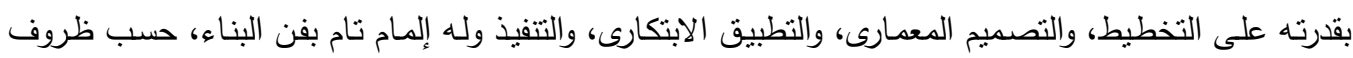
البيئة ومقتضياتها، ويسهم فى التعمير والتشييد، فى نطاق التخطيط العام، ويتمتع بالحماية القانونية التىى تتطلبها

منتنه. ويشترط أن يكون حائزاً على بكالوريوس فى الهندسة المعمارية أو ما يعادلها من المؤهلات الهندسية الأخرى، المعترف بها بقانون نقابة المهندسين، وأن يكون عضون الموراً بنقابة المهندسين.

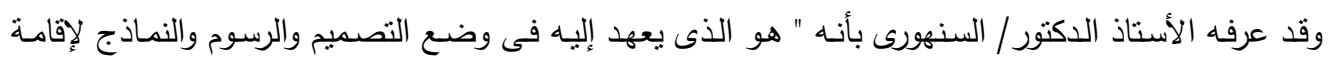

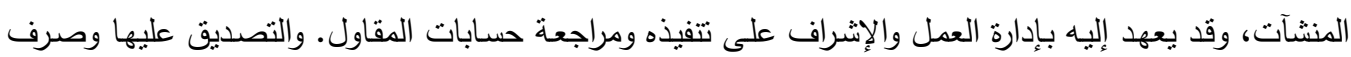
المبالغ المستحقة إليه(3). وعلى ذللك فحاصل هذه التعاريف جميعها أن المننس المعمارى هو الثخص الطبيعى الهتميز بملكاته الذهنية،

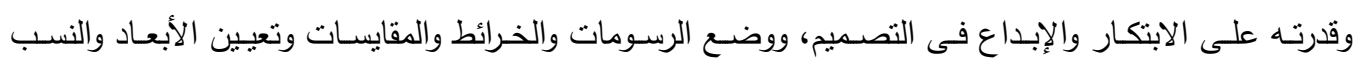

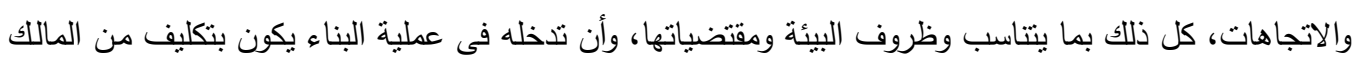

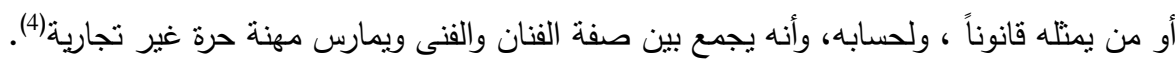

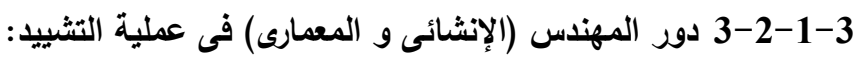

(1) انظر... إدوارد لابـان فى رسـالته " مسئولية المهندسين المعمـاريين و التأمين منهـا" ، المقدمة إلى

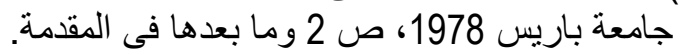

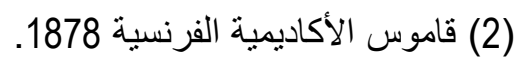

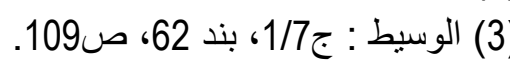

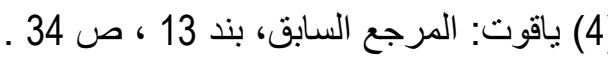


المهندس الإنشـائى: مسئول عن تصميم وتتفيذ وسـلامة أى منشـأ تتخيله من حيث تسليح قطاعات

الأعمدة بحيث تتحمل القواعد الداخلية والخارجية للمنشآت.

وإذا كانت مهنة المهندس المعمارى قد اختلطت مع مهنة المقاول، ردحاً طويلاً من الزمن بحيث كان بعض المقاولين يقوم بتصـيم البنـاء وتتفيذه، فيمارس بذللك المهنتين معاً، وكذلك كان حسال بعض المهندسين

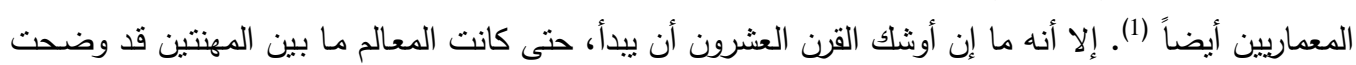
تماماً، وتميزت كل منهما عن الأخرى.

فحيث اختصت الأولى بوضع التصميم والرسومات والمقايسات وأحياناً الإدارة والإشراف، اقتتعت الثانية

بدور التتفيذ، وعلى ذلك أصبح المهندس المعمارى ذلك الفنان الذى يتميز بأنه يمارس مهنة حرة (2) تختلف عن مهنة كل من المقاول ، والمورد فى أنها مهنة حرة غير تجارية، لا تسعى إلى الكسب ولا تضارب عليه (3).

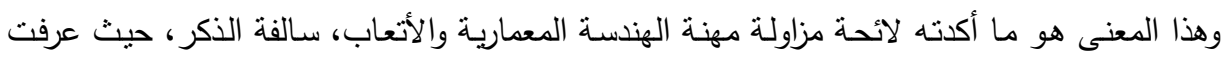

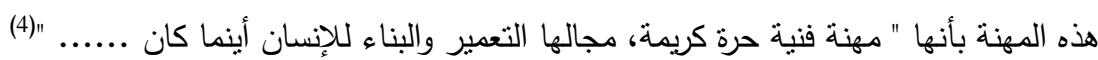

3-2 المبحث الثانى: أنـواع العيـوب التى توجب مسئولية المهندس (الإنثائى أو المعمارى).

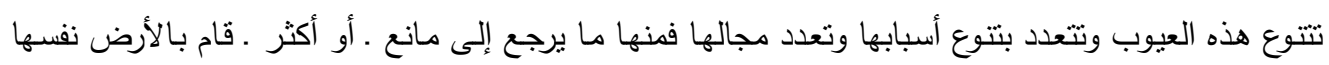

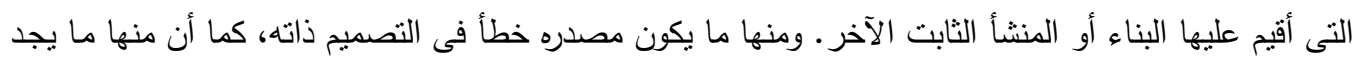
أساسـه فى المواد المستعملة فى التشييد، كذلك فإن منها ما يكون منشؤه خطأ في عملية التشيبيد والبناء ذاتها، وأخيراً فقد يكون سبب العيب مخالفة القوانين واللوائح المنظمة لهذا المجال من مجالات النشاط البشرى، لكن لما كان هذا العيب الأخير ليس عيباً قائماً بذاته، وإنما هو عيب منصل بكل نوع من الأنواع الأربعة الأولى، لذلك

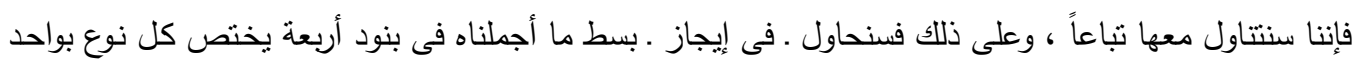

(1) حتى لقد عرفه قاموس الأكاديمية الفرنسية فى طبعته 1762، 1798 بأنه : الشخص الذى يمارس فن

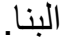

(2) انظر نقض مدنى فرنسى فى 14 من ديسمبر 1897 دالوز 1911 - 1 - 584 حيث قررت فيه : أن

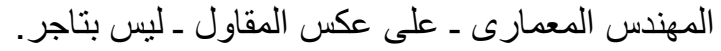

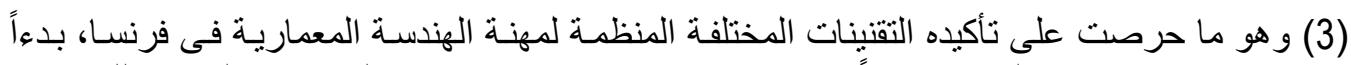

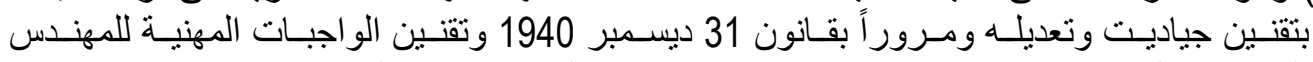

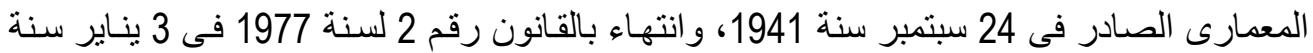

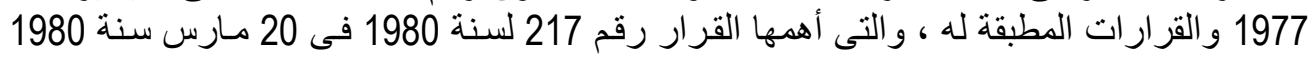

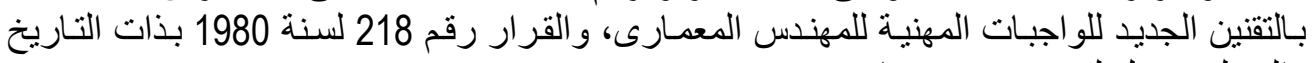
و المتعلق بحمل لقب مهندس معمارى. (4) هذا وينظم مهنـة الهندسـة المعماريـة فى مصر حاليـاً قانون نقابـة المهندسين رقم 66 لسـنة 1974

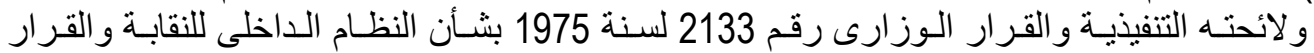

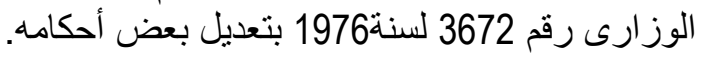


1-2-3 المطلب الأول: العيب الناشئ عن فحص التربة .

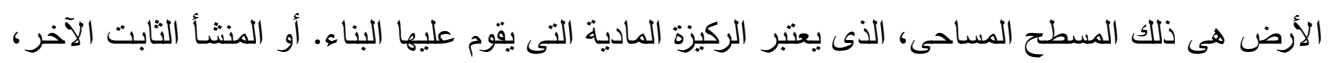

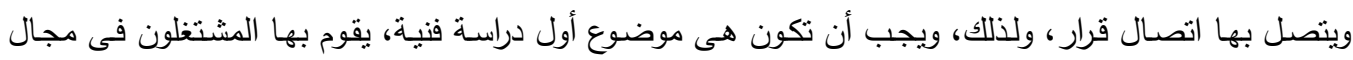

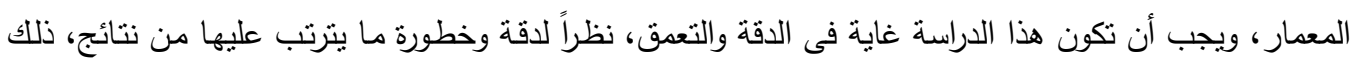

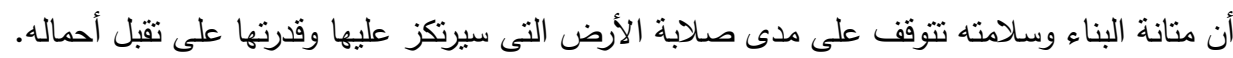

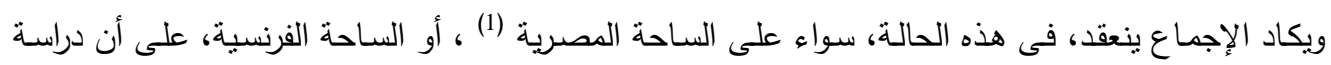

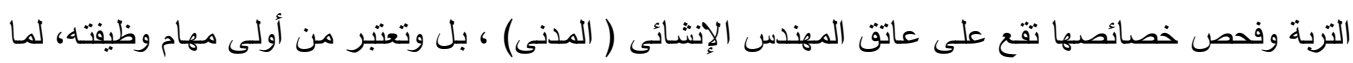

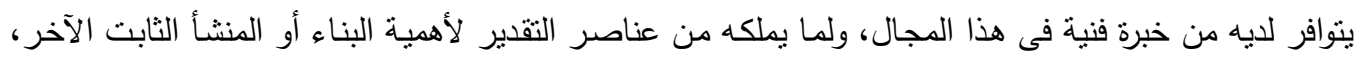
المزمع إنشاؤه، ومدى استجابة خصائص النربة له.

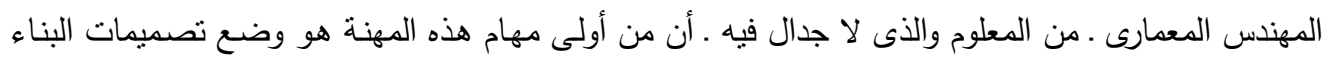

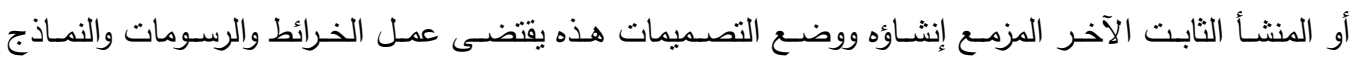

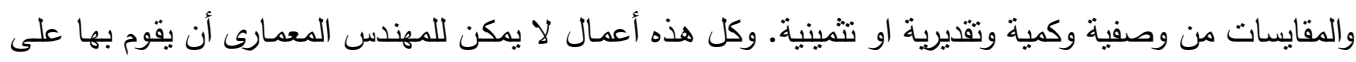

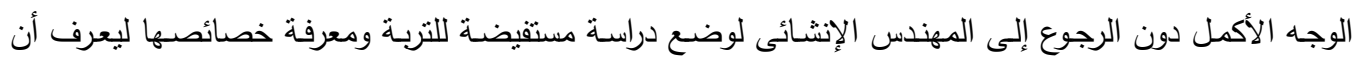

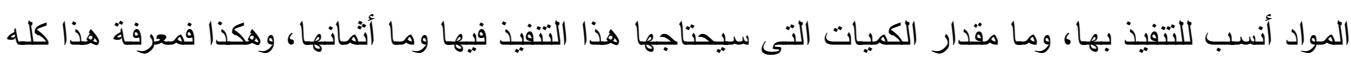

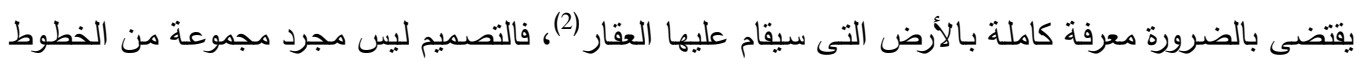

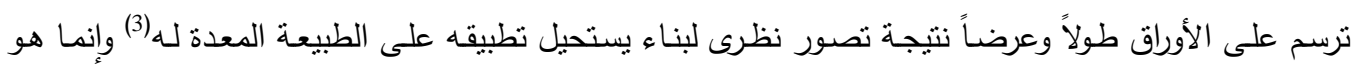

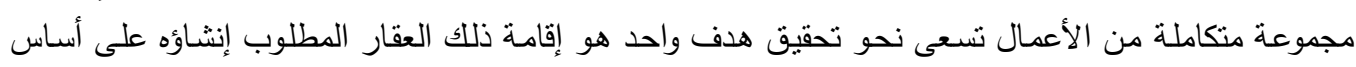
سليم، وخال من العيوب التى تسبب تهدمه أو تهدد سلامته ومنانته.

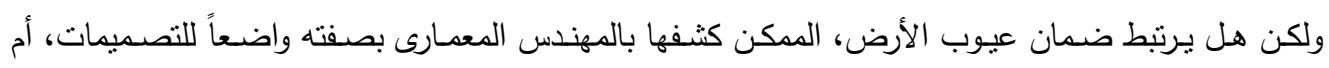

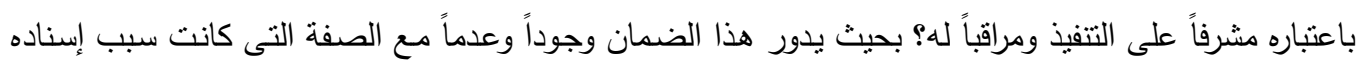
إليه.

ينبغى أن نبين أن هناك حالة معينة لا ينطرق إليها الثنك فى القول بمسئولية المهنس المعمارى واضع التصميم

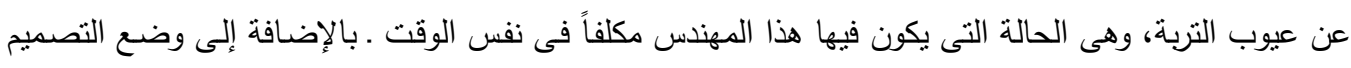

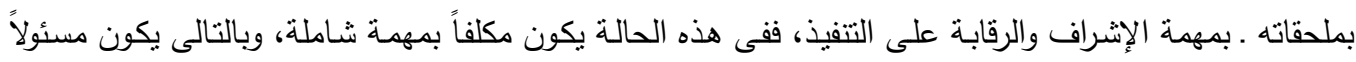

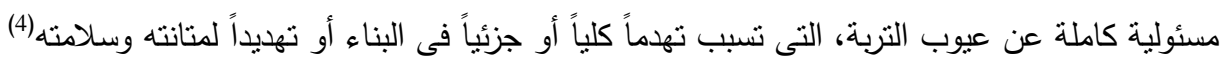

(1) فتحى غيث: قانون المهند، ص54 ـ ـ ـ ياقوت: المرجع السابق، بند 40 ، ص98 وما بعدها.

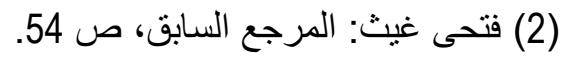

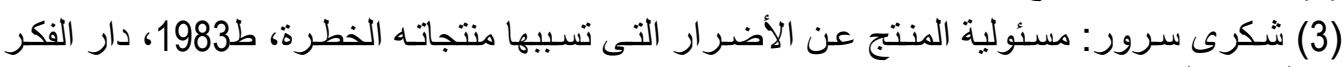

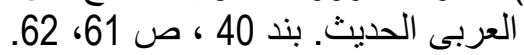

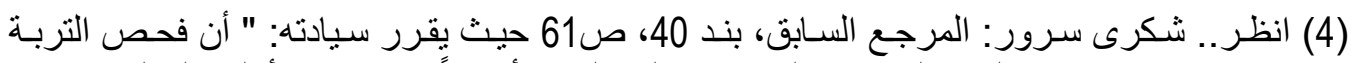

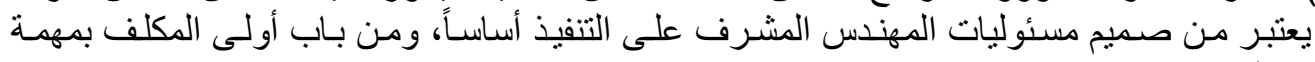


أما الحالة التى بثور بشأنها هذا التساؤل، فهى حالة المهندس المعمارى الذى يكلف بوضع التصميم فقط، دون

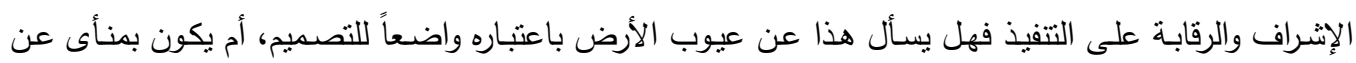

المسئولية عن هذه العيوب حيث لم يكلف بالإشراف والرقابة على التتفيذ، بل تقتصر فقط على من يكلف بهذا. يذهب جانب من الفقه الفرنسى إلى أن هذا المهندس المعمارى لا يضـمن عيوب الأرض إلا إذا كان مكلفاً بالإشراف على الأعمال ومراقبة التتفيذ.

فى حين يرى جانب آخر من هذا الفقه أن المهندس الإنشـائى يظل ضـامناً لعيوب الأرض، ولو لم يكلف بالإثراف والرقابة على تتفيذ الأعمال، أى ولو اقتصر دوره على مجرد وضع التصميمات والمقايسات فقط، مستتداً فى ذلك على أن جس التربة ـ أى فحص التربة . وهكذا قضى بـأن وضـع التصميمات والمقايسـات الوصفية والكميـة للمشروع من جانب المهندس المعمـارى، يقتضى من المهندس الإنشائى دراسة جادة للتربة التى سيقام عليها البناء.

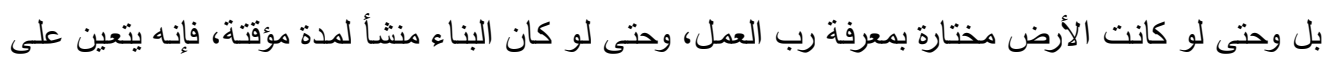

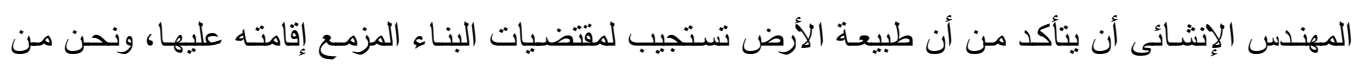
جانبنا أميل إلى هذا الرأى لما سبق أن أبديناه.

\section{1-1-2-3 المواتع التى تقوم بالأرض:}

هذه الموانع قد تكون قانونية كما قد تكون طبيعية. فأما عن القانونية منها ، فمثالها أن تكون الأرض مملوكة للدولة أو للأغيار ، أو منزوعة ملكيتها للمنفعة العامة،

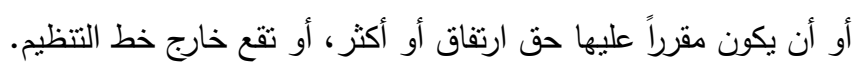
والكثف عن هذه الموانع ليس فى حاجة إلى عناء ذلك أنه بمكنه المهندس المعمارى أن يطلب من رب العمل العل مستتدات ملكتيه لهذه الأرض، كى يتأكد من الملكية وحدودها.

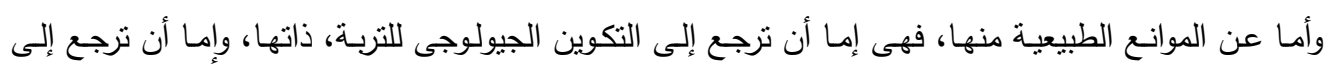
أسباب الجوار . فأما عن الأولى منها: فقد تكون التربة رملية أو طَفلية إلى امتداد بعيد فى باطن الأرض، أو نربة ردمية ناتجة

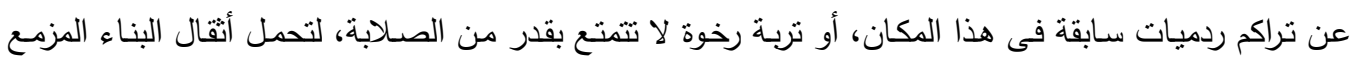

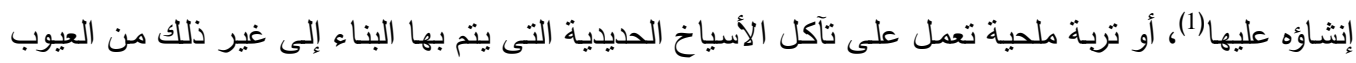
التى ترجع إلى طبيعة التكوين الجيولوجى للتربة. وأمـا عن الثانيـة منها وهـى التى ترجـع إلى أسباب الجوار : فمنها: أن تقع الأرض المزهـع إقامـة البناء عليها بالقرب من حافة نهر أو بحر، بحيث تكون مهددة بتلاطم الأمواج وتأثيرات المد والجذر أو فعل الرطوبة، أو تكون

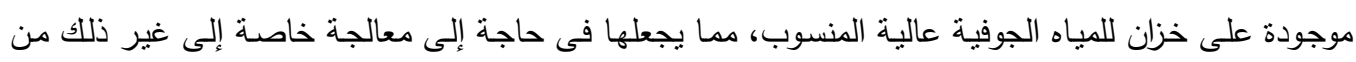


أسباب وعوامل تجعل الأرض غير صالحة كلياً أو جزئياً لتحمل أثقال البناء أو المنشأ الثابت الآخر ، المراد إقامته عليها. وعلى ذلك فإن أول عمل يجب أن يقوم به المهند المعمارى ـ أو المقاول على حسب الأحوال ـ بعد الثأكد من

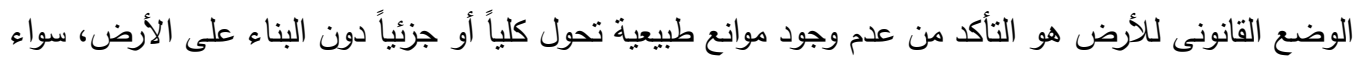

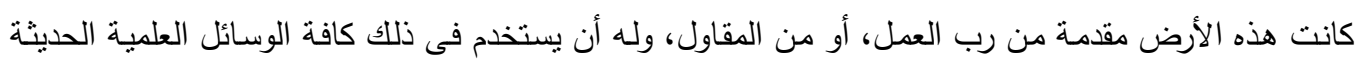

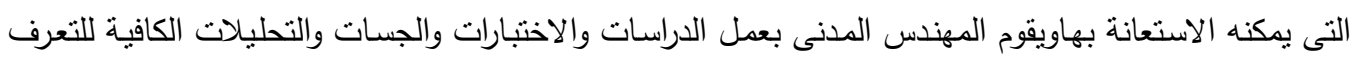

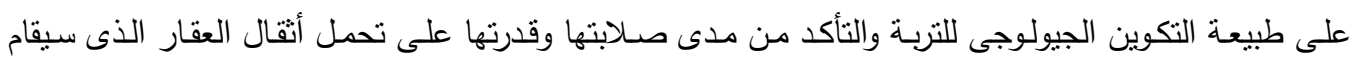

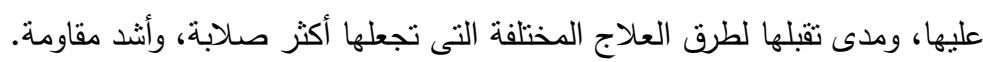

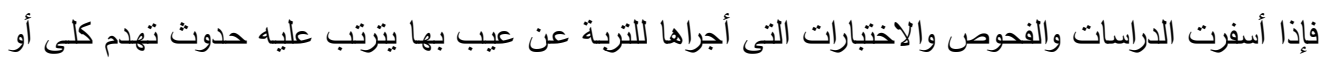

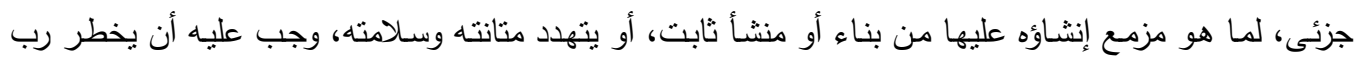
العمل حالاً بالنتيجة. على أن العيب فى الأرض الذى يسأل عنه المهندس الإنشائى طبقاً لأحكام هذه المسئولية الخاصة، يجب أن

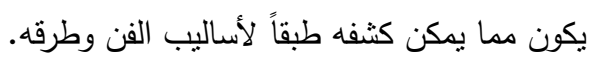

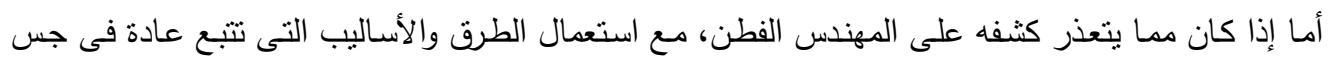

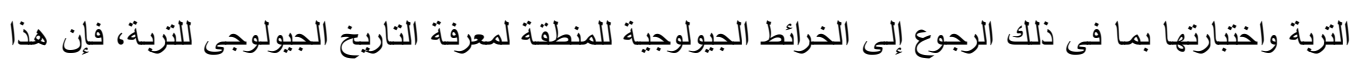
يعتبر من قبيل القوة القاهرة النى يتحلل المهنس الإنثائى بها من هذه المسئولية.

2-2-3 المطلب الثانى : العيب الناشئ عن خطأ فى التصميم .

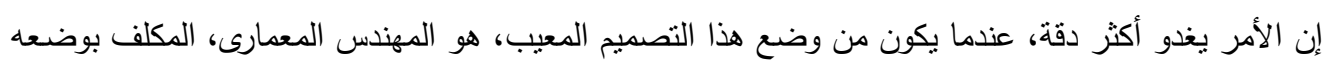

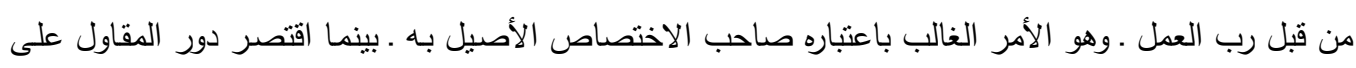

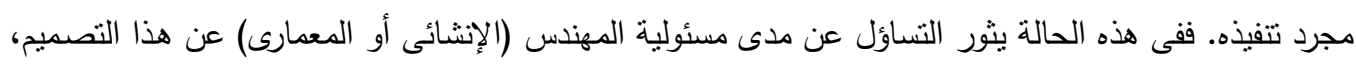

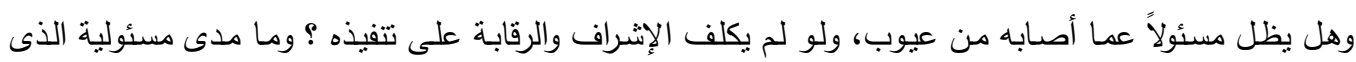

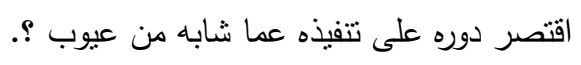

لاثثك أن المهندس المعمارى ملتزم بمقتضى العقد المبرم بينه وبين رب العمل التزاماً بنتيجة مقتضاها، أن يقدم

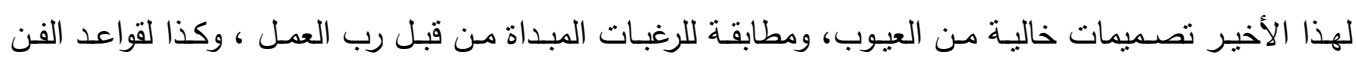

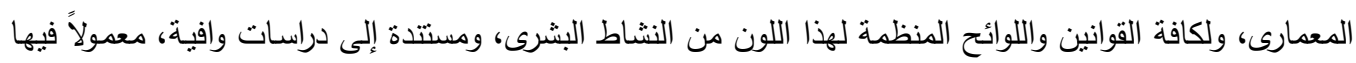

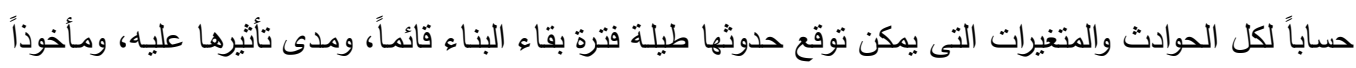
فى الاعتبار كافة الظروف المحيطة بالموقع (1).

(1) باقوت: المرجع السابق، بند 42 ، ص ص 102وما بعدها.

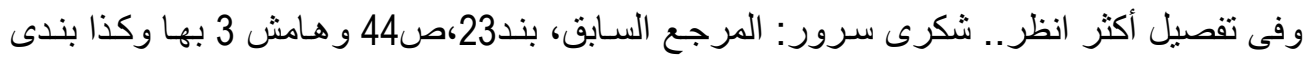

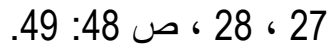


فإذا ما قدم المهندس المعمارى ـ على العكس من ذللك ـ تصميمات معيبة بعيوب ترتب عليها جعل العقار غير

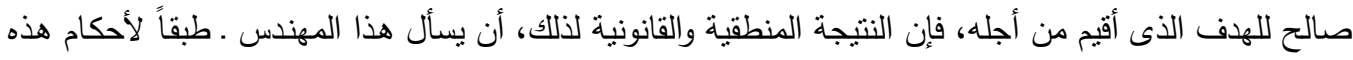
المسئولية الخاصة. عن هذه العيوب التى تضمنها تصميمه، والتى أسفرت عن هذه الأضرار ، لأنه كان قد التزم

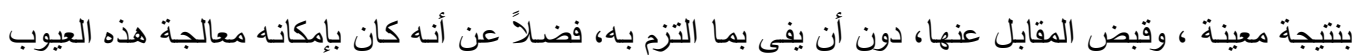
أثثاء إثرافه على التنفيذ، فحقت لذلك مساءلته.

لكن هل يظل المهندس المعمارى ضامناً لعيوب تصميمه ، ولو لم يكلف الإشراف والرقابة على التتفيذ؟. يجمع الفقه المصرى ـ ممن تعرض لهذه المسألة ـ على الإجابة على هذا التساؤل بالإثبات .

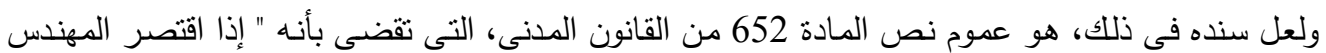

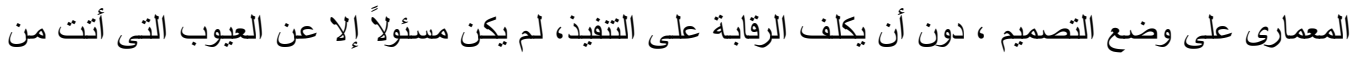

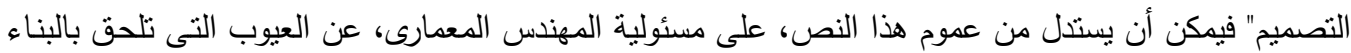

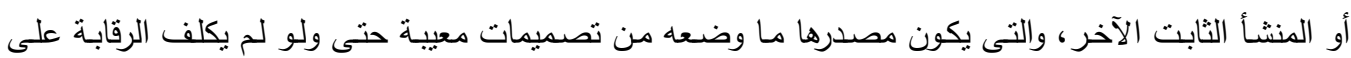
التتفيذ، وهذا فى الحقيقة قول منطقى يتفق وطبائع الأمور ، فما كان ينبغى لأحد غيره أن يحمل وزره. وعلى ذلك، ولكل ما قدمنا فإننا نرى مع إجماع الفقه المصرى، والأغلبية الساحقة من الفقه الفرنسى، التى يؤيدها القضاء، أن المهندس المعمارى بظل مسئولاً عن ضمان العيوب التى تصيب ما وضعاه من تصميمات، وما عمله من مقايسات، حتى ولو لم يكلف بالإشراف والرقابة على تتفيذ ما وضعه ، ولم يقم رب العمل بتكليف آخر بذلك.

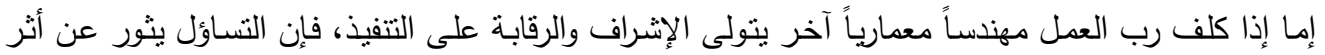

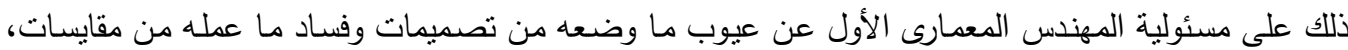
هل تتنهى بهذا التكليف مسئوليته؟ أم تظل باقية رغم ذلك؟. إن المهندس المعمارى الذى لا يكلف الإشراف والرقابة على تتفيذ ما وضعه من تصميمات، لا يكون مسئولاً. . كقاعدة متى أسند الإشراف والرقابة على التتفيذ إلى مهندس معمارى آخر . عن عيوب هذه التصميمات التى غدت التى

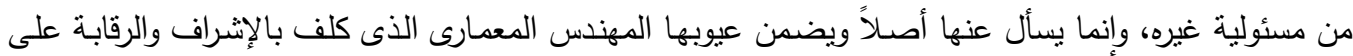
تتفيذها بعد أن قام بفحصها ومراجعتها.

3-2-2-3 مدى مسئولية المقاول الذى اقتصر دوره على التتفيذ عن عيوب التصميم الذى وضعه المهندس المعمارى المكلف بوضعه من قبل رب العمل.

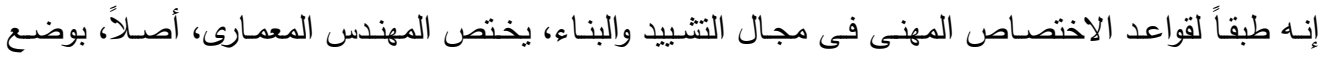
التصميمات والدقايسات اللازمة للمشروع، فى حين يختص الدقاول بتتفيذها، فإذا ما أتت هذه التصميمات معيبة

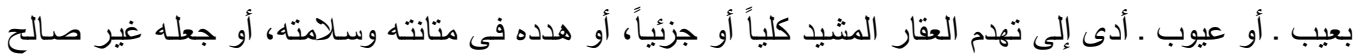

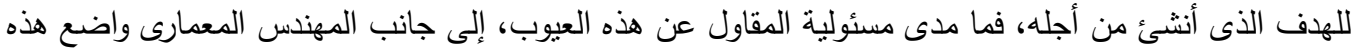

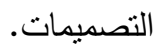
إن المقاول لا بسأل عن تهدم أو تعيب فى البناء الذى شيده، أو المنشأ الثابت الذى أقامه، عندما يكون قد نفذ بكل دقة وأمانة التصميمات، والدقايسات النى وضعها المهندس المعمارى، ولكن الحكم لا يكون كذلك، إذا كانت 
هذه التصميمات والمقايسات، واضحة الفساد، ظاهرة العيب، كما لو كانت مخالفة لقواعد الفن، التى لا يمكن أن

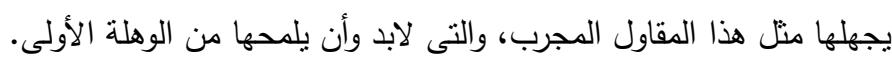

\section{2-2-3-3 بعض مظاهر الذطأ فى التصميم بالنسبة للمهندس الإنثائى:}

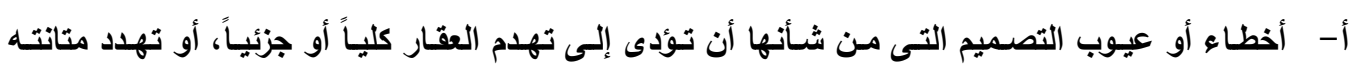

وسلامته.

من هذه الأخطاء ما يكون منشأه مخالفة قواعد الفن المعمارى ذاتها، كما أن منها ما يكون مرجعه إلى مخالفة

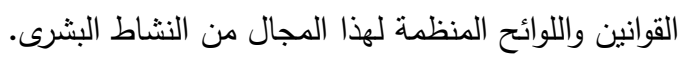

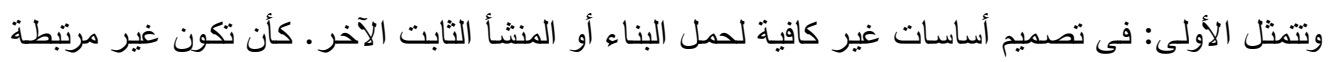

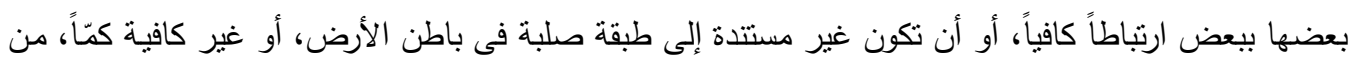

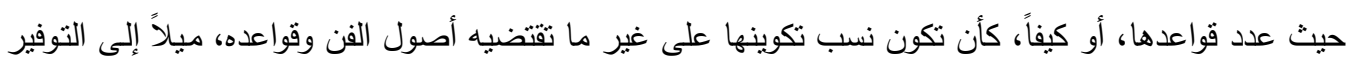

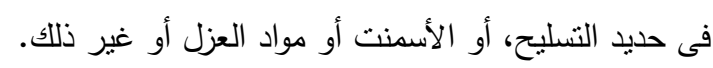

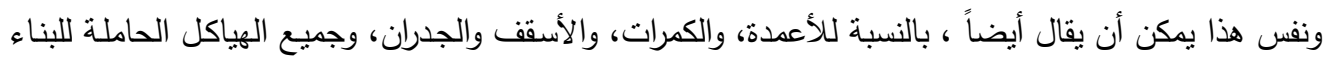

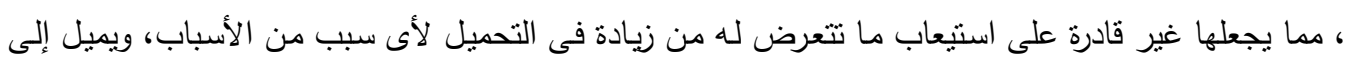
على ناحية الضعف الذى يؤدى إلى ظهور العيب بها.

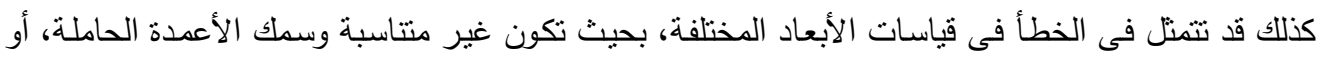

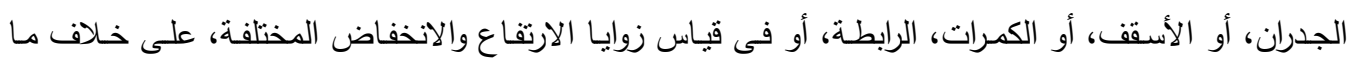

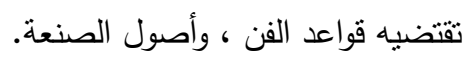
كما يمكن أن تتمثل أيضاً فى الخطأ فى تصميم المنافع العامة بالبناء، كالخطأ في تحديد أماكن دخول مياه

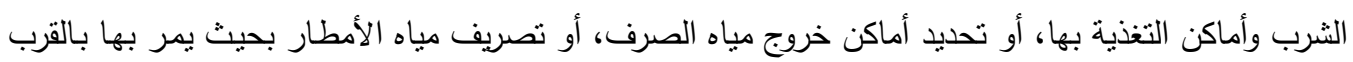

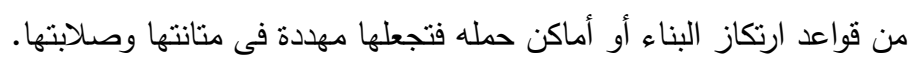

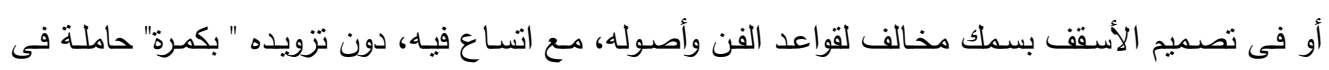
منتصفه، بحيث تكفل له مقاومة أكيدة تحول دون سقوطه.

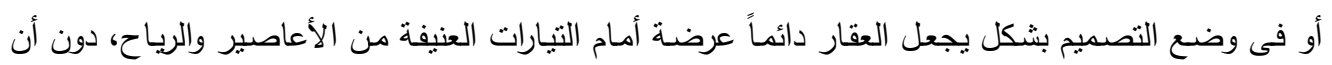

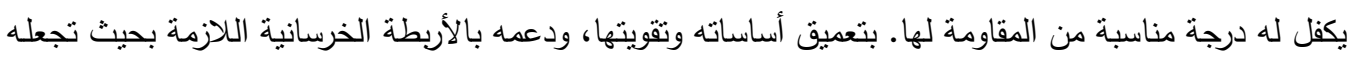
يصمد لمثل هذه الثنيارات.

أو وضع تصميم لبناء، على خزان للمياه الجوفية، أو بالقرب من شاطئ البحر ، دون اتخاذ الاحتباطات الكافية

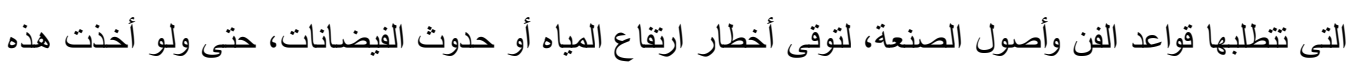

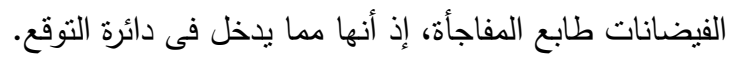

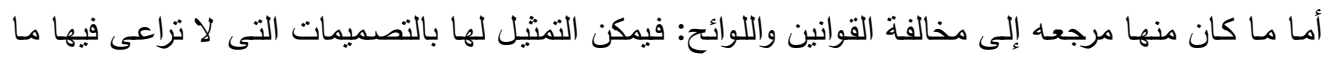

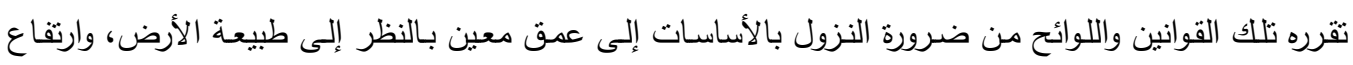
البناء المزمع إنشاؤه واستعمالاته المعد لها. 
أو من ضرورة أن تكون الجدران من سمك معين، رقة وكثافة، حسب مكانها من البناء، ارتفاعاً أو انخفاضاً، داخلياً أو خارجياً، داعمة أو ضون غير داعمة، وهكذا. أو من ضرورة أن تكون الأساسات أو الركائز أو الأعمدة الخرسانية بنسب داعيدة معينة من مواد تكوينها المختلفة من

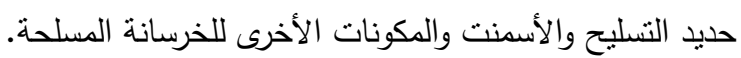
أو أن تكون من أحجام معينة، مأخوذاً فى الاعتبار بعدها أو قربها بعضها لأنها البعض، أو الو الأحمال المعدة لحملها،

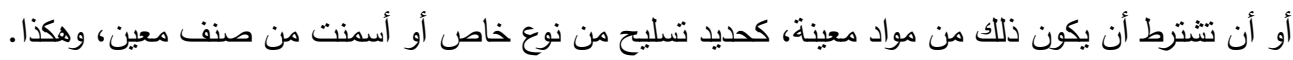

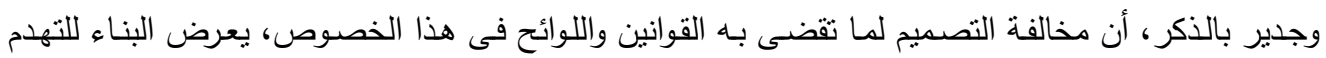

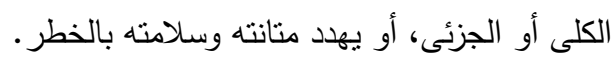
كذلك قد تكون المخالفة منصبة على الناحية التظيمية كتجاوز خط التنظيم، أو تجاوز قدر الارتفاع المسموح

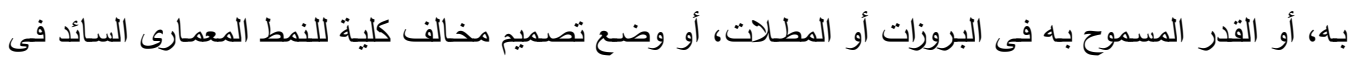

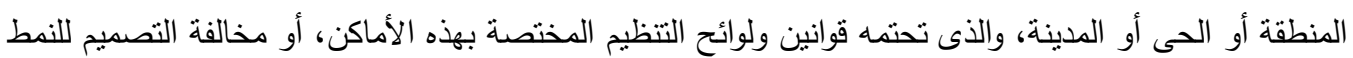

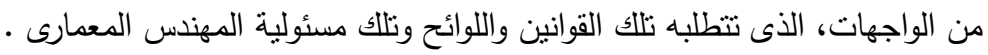

3-2-2-3 أخطاء أو عيوب التصميم التى من شأنها أن تجعل البناء، غير صالح لأداء الهيف الذى شيد من أجله. يمكن حصر هذا النوع فى ثنلاث مظاهر : إغفال الغرض من البناء ذاته، أو إغفال الجانب الجمالى فيه، أو إهدار عوامل الراحة والأمان فى استعماله.

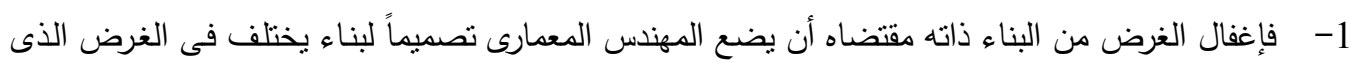

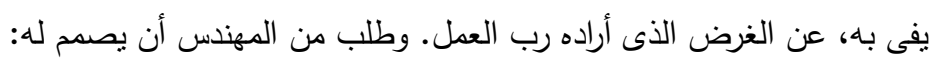

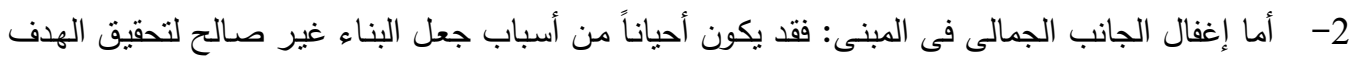

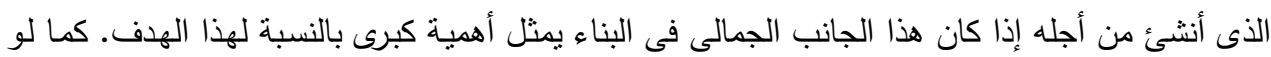

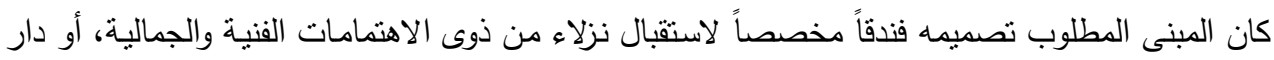

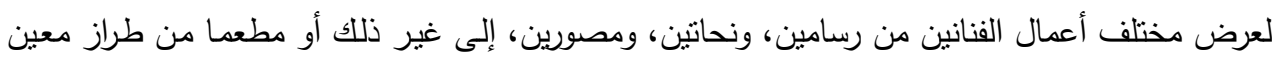

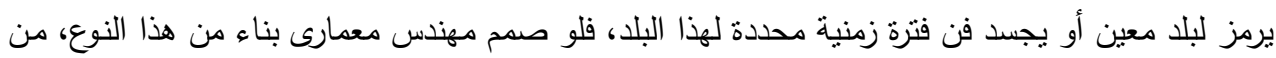

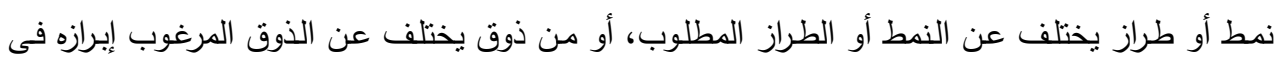

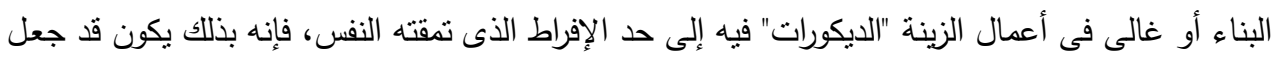

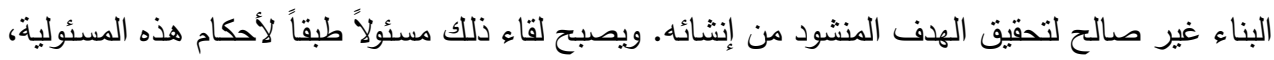

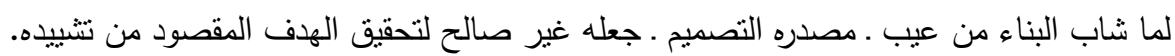

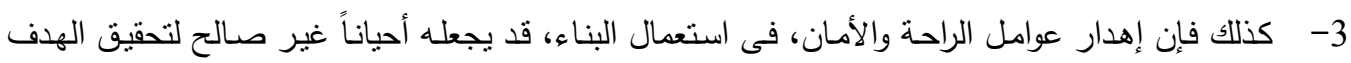
المنشود منه، مثال ذلك: تصميم مصحة لمرضى الأمراض العصبية، غير مستوفية لمقتضيات العزل

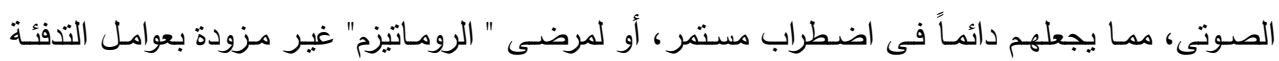


المناسبة، أو لمرض الصدر، تتقصها عوامل التهوية، التى يتطلبها هذا النوع من المرض. أو لمرض العيون

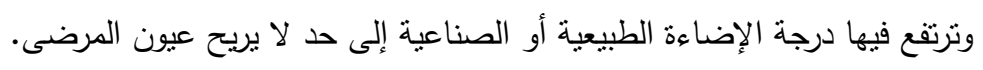

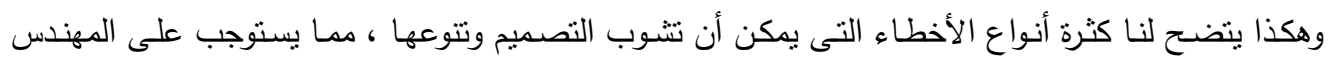

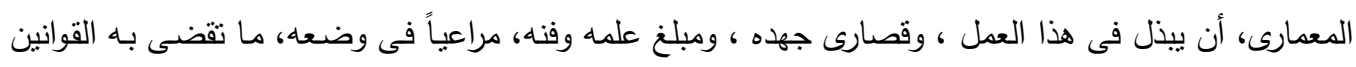

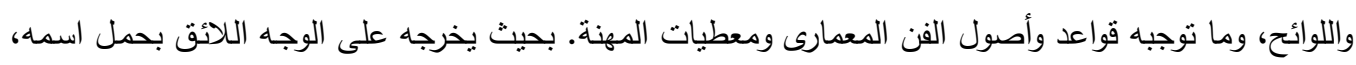

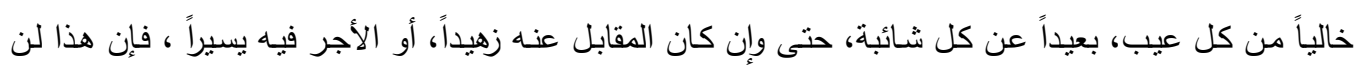
يعفيه من المسئولية، جنائية ومدنية، خصوصاً إذا علمنا خطورة ما يترتب على التقصير فيه من حوادث، وبشـاعة ما يحدث بسبب الخطأ فيه من كوارث.

3-2-2-2-3 الخطأ فى التصـيم و فى المقايسـات: التى يضعها المهندس المعمـارى عند وضـعه للتصميم ، والمقايسات التى قد ينرتب على الخطأ فيها تهدم فى البناء أو تعيبه بعيب يهدد منانته وسـامته هى ولى المقايسـة الوصفية والمقايسـات الكميـة ـ ويحسن أن نعرف كل نوع منهـا مردفين عليه بيـان مظهر

$$
\text { الخطأ فيها ومدى جسامته. }
$$

المقايسة الوصفية: هى عبارة عن بيان كتابى يضعه المهندس المعمارى، يوضح فيه انواع المواد المختلفة اللازمة لتتفيذ التصميمات التى وضعها، وطبيعة كل نوع، وصفاته وخصائصه التى تميزه عن غيره ، وكيفية استخدامها.

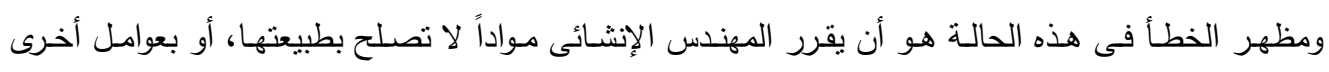

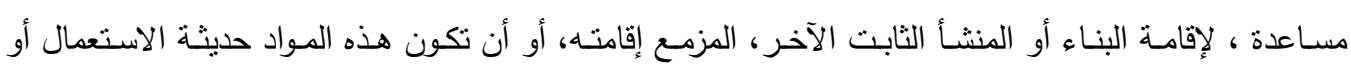

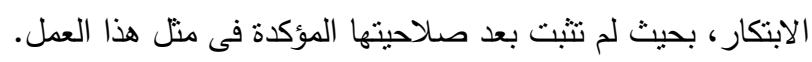
والمهندس الإنشائى بوقوعه فى مثل هذه الأخطاء، عند وضعه لهذا النوع من المقايسات، يعرض نفسه للمساعلة

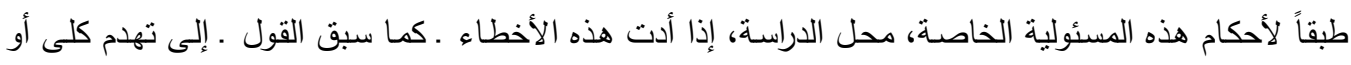

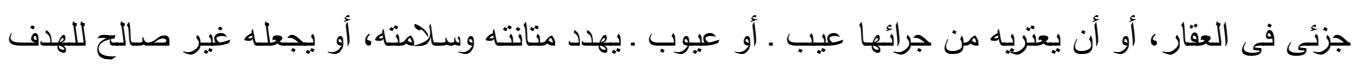
الذى أنشى من أجل الوفاء به.

أما المقايسة الكمية: فهى على العكس من المقايسات الوصفية ـ لا تلتعلق بكيف المواد اللازمة لتتفيذ التصميم،

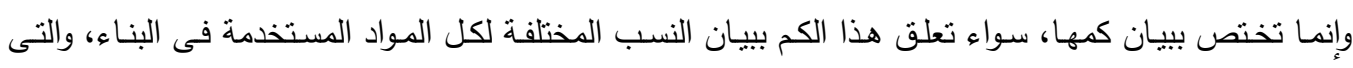
باندماجها معاً، وصبها فى قوالبها المعلومة، ينتج هيكل البناء المراد نشييده، أو تتعلق ببيان الكميات الإجمالية من ين المواد، المطلوب الحصول عليها لتشييد البناء. ومظهر الخطأ فى هذا النوع من المقايسات، يتعلق أكثر بالكم النسبى، وليس بالكم الإجمالى، إذ أن الخطأ فى

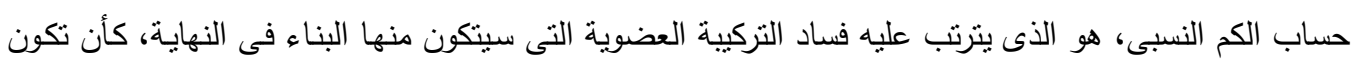
الخرسانة المسلحة مكونة من نسب متفاوتة جداً من المواد المختلفة، أو تكون نسبة حديد التسليح غير كافية بدرجة غير مألوفة.

ولاشك أن فساد هذه التركيبة، مما يترتب عليه ـ حسب نسبته . حدوث تهدم فى البناء، كلياً كان أو جزئياً، أو

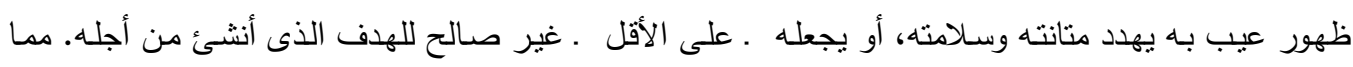


يستوجب مسئولية المهندس الإنشائى واضع هذه المقايسات المعيبة أو التى كان من نتيجتها حدوث هذه الأضرار

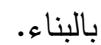

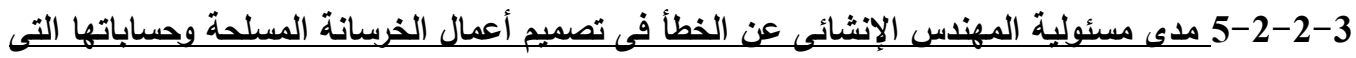

\section{يضعها المهندس أو مكتب دراسات متخصص فيها:}

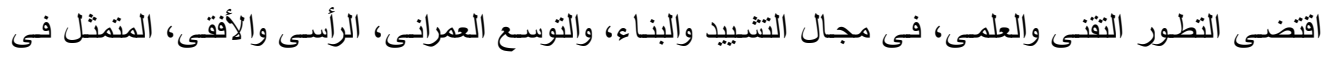

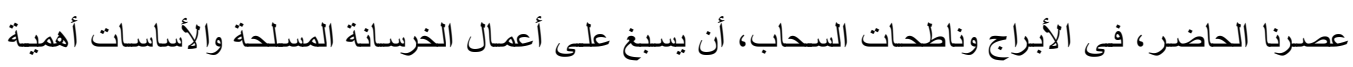

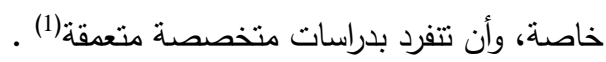

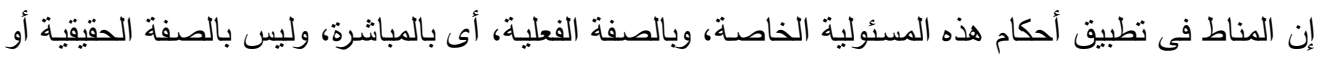

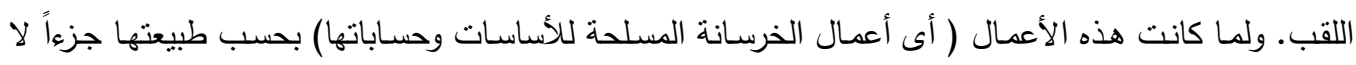

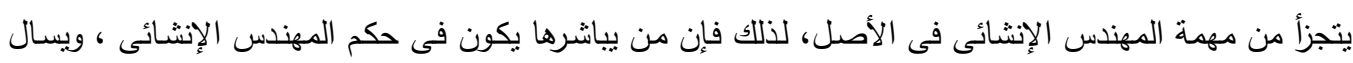

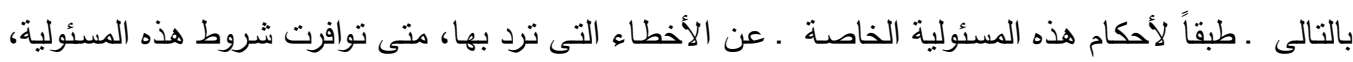
وموجبات تطبيق أحكامها.

3-2-3 المطلب الثالث : العيب الناشئ عن المواد المستعملة فى التثييد .

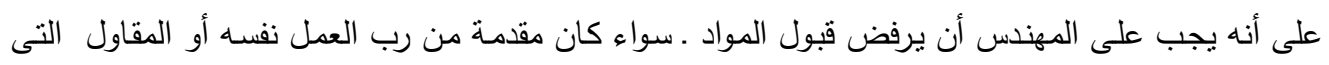

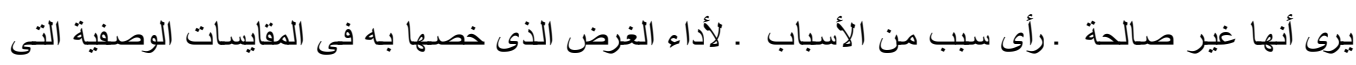

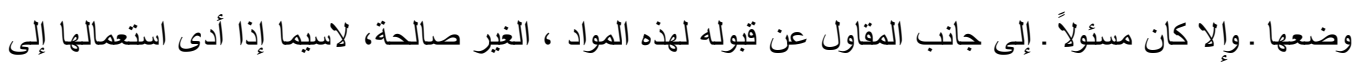

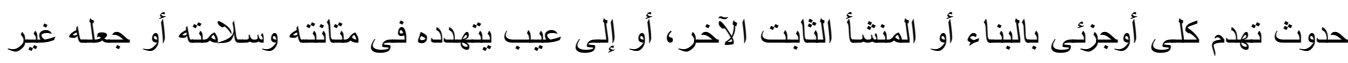
صالح للهدف الذى شيد من أجله.

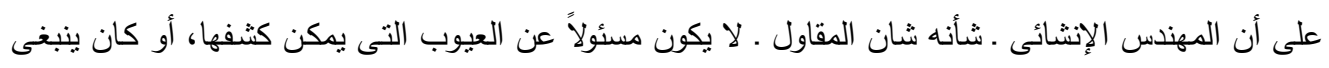

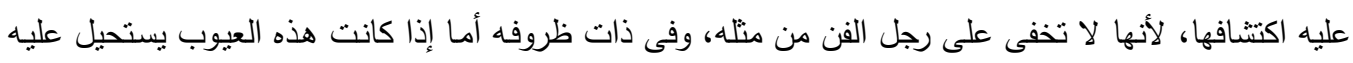

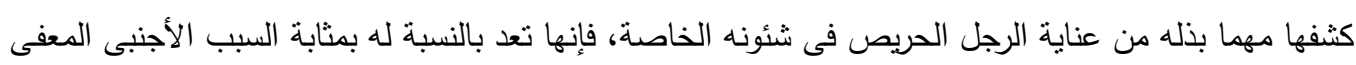
من المسئولية إذ الأصل ألا تكليف بمستحيل.

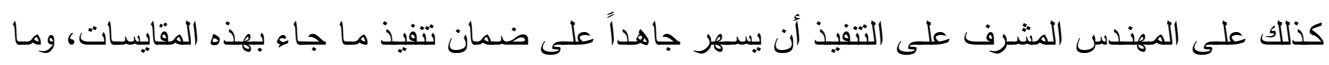

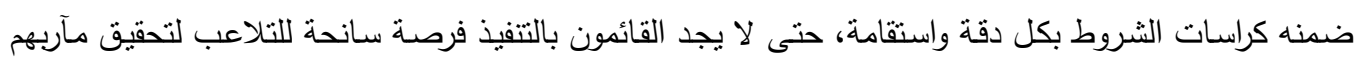

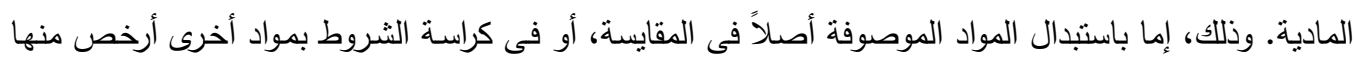

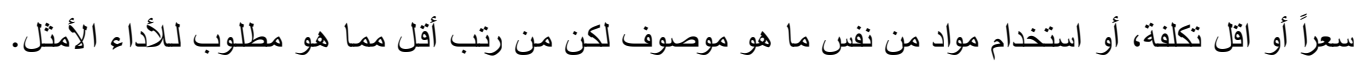

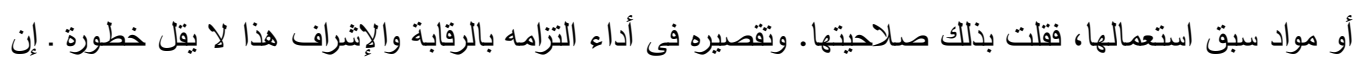

(1) شكرى سرور: المرجع السابق، بند 26، ص47. 
لم يزد ـ من الناحية العملية تقصيره فى التزامه السابق ـ فنتيجة كلا التقصيرين، قيام مسئوليته ـ طبقاً لأحكام هذه المسئولية الخاصة ـ منى توافرت شروطها من شكلية وموضوعية.

4-2-3 المطلب الرابع : العيب الناشئ عن خطأ فى التنفيذ .

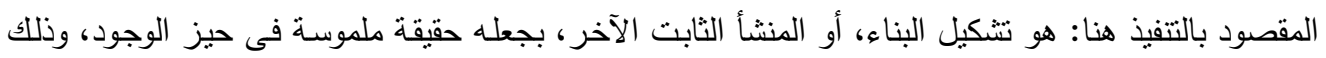

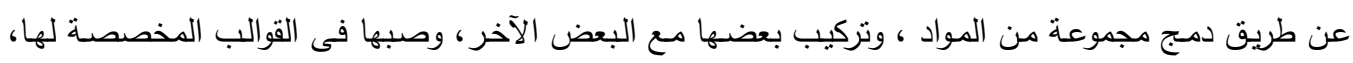

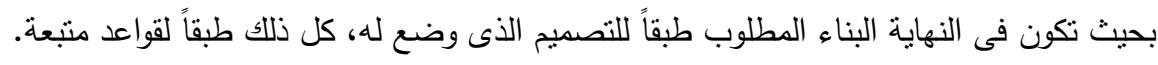

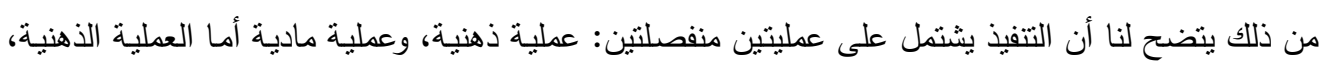

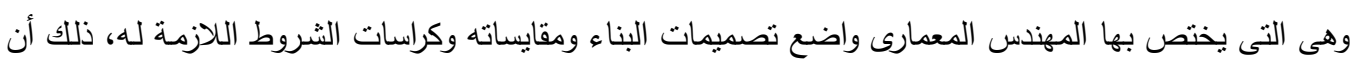

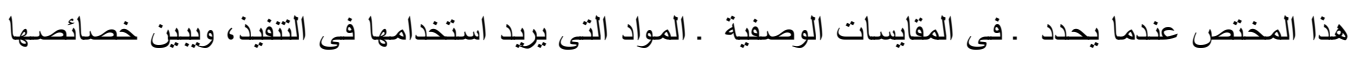

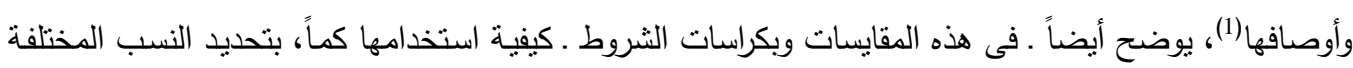

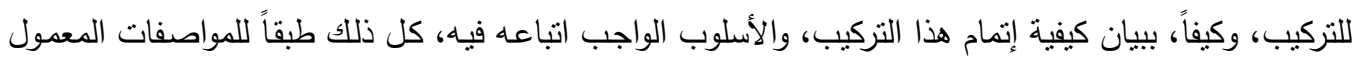
بها، وقواعد الفن وأصول الصنعة، وبما يتفق والقوانين واللوائح المنظمة.

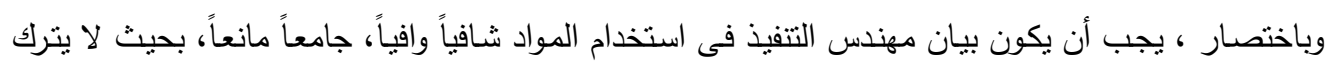

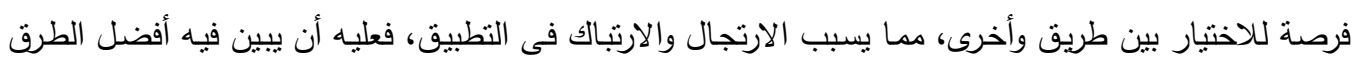

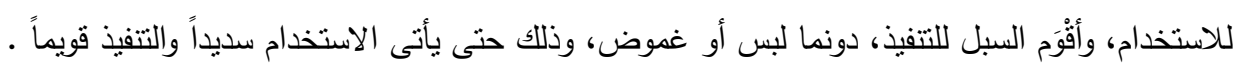

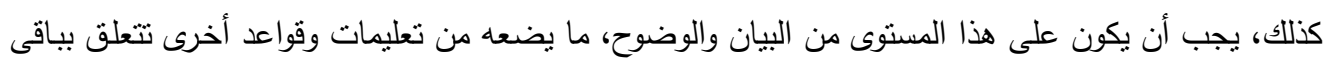

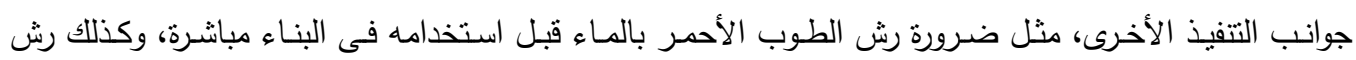

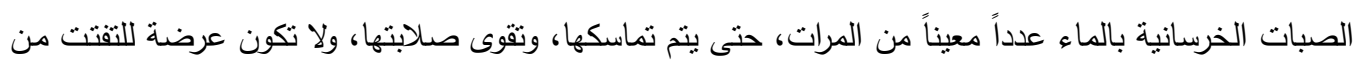

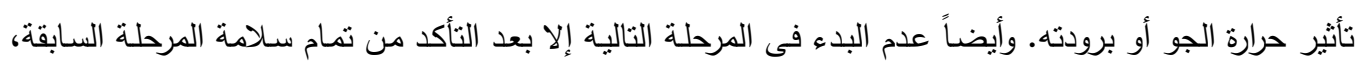

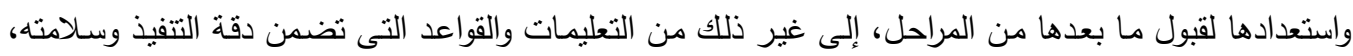

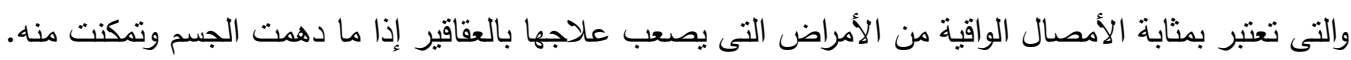

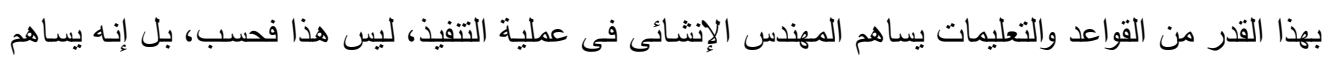

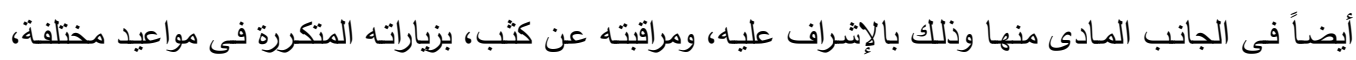

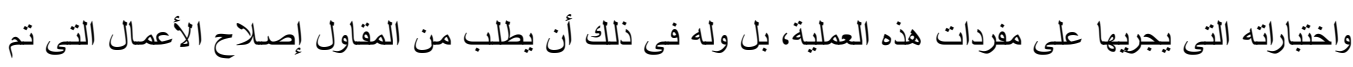
تتفيذها تتفيذاً معيباً.

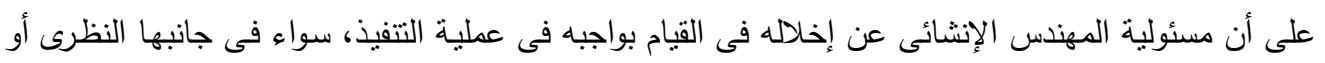

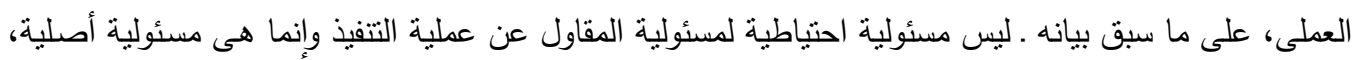

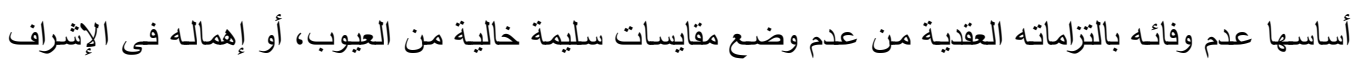
والرقابة على عملية التنفيذ، على خلاف مقتضى العقد المبرم بينه وبين رب العمل.

(1) هذا فيما يتعلق بدور المهندس المعمارى فى اختيار المواد، بالإضـافة إلى دوره فى الرقابـة عليها عند نوزيعها من قبل رب العمل أو المقاول. 
قد يكون العيب فى عملية التشييد والبناء راجعاً إلى عدم مراعاة الترتيب الزمنى بين العمليات المختلفة المكونـة للبناء، أو المنشأ الثابت الآخر ، بحيث لم تأخذ كل عملية من هذه العمليات حظها الكافى من

الوقت كى يتم جفافها وتكتمل صلابتها، ويقوى تماسكها، حتى تكون قادرة على حمل المراحل التالية عليها.

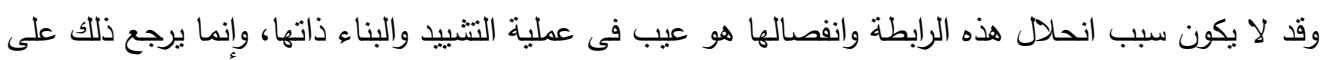
عيب فى المواد نفسها، المستعملة فى هذه العملية كأن تكون تالفة نتيجة رطوبة أو تبلل لحقها أو معاد استعمالها، فتذهب بذلك خاصية التماسك بين جزئياتها، أو تكون من صنف ردئ لا يصلح لتأدية الغرض المقصود منها من فن فئس شد أجزاء البناء بعضها إلى بعض، وإحكام ربطها وتماسكها. وكما أنه لا يهم فى انحلال هذه الرابطة، أن يكون بسبب عيب فيى عملية النتييد والبناء ذاتها، أو بسبب عيب فى المواد نفسها المستعملة فى هذه العملية، فكذلك الحال، إذا ما كان هذا الانحلال فى الرابطة، التى تربط بين

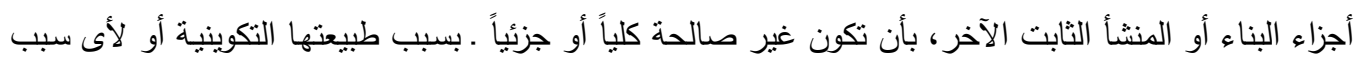
آخر . للبناء عليها ، أو إقامة منشآت أخرى، شريطة أن يكون عيب الأرض هذاء مما يمكن كثفه وفقاً لقواعد الفن. أما إذا استحال كثف عيب الأرض، وفقاً لهذه القواعد، فإن ذلك يكون من قبيل القوة القاهرة و لا يكون المهندس مسئولاً عنه. هذا ولقد حرص كل من المشرعين، المصرى والفرنسى، على الإفصساح عن قصدهما فى سريان أحكام هذه

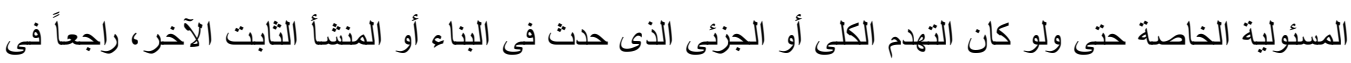
أساسـه إلى عيب فى الأرض ذاتها، وذلك بالنص الصريح على ذلك فى كل من المـادتين 621 مدنى مصرى، 1972 مدنى فرنسى، إذ تقضى كل منهما بأن الضمان يكون مقتضى ولو كان التهدم راجعاً فى سبيه إلى عيب دئ دئ الأرض ذاتها.

كذلك قد يكون سبب التهدم ـ كلياً كان أم جزئياً . عيباً فى التصميم ذاته، لعدم مراعاة الأصول الفنية فى وضعهه، طبقاً لأصول الهندسة المعمارية، وفى هذه الحالة، يكون المهندس المعمارى الذى قام بوضع هذا التصميم المعيب،

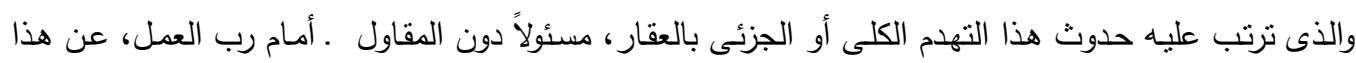

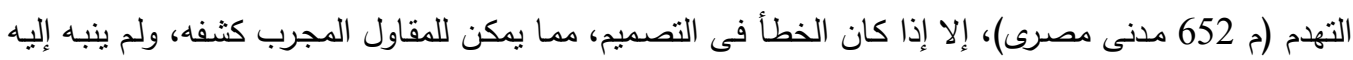

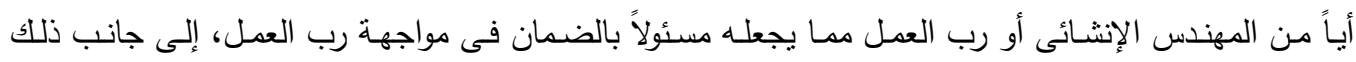

المرندس.

ولكن إذا كان ليس ثــة خلاف قد ثار بالنسبة لنطبيق أحكام هذه المسئولية الخاصـة عندما يكون التهدم . كلياً

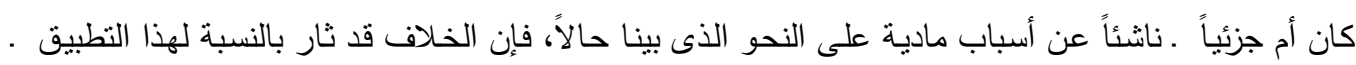
لاسيما فى الفقه الفرنسى . عندما يكون التهدم معزواً إلى عيب قانونى شابل شاب عملية التشييد والبناء.

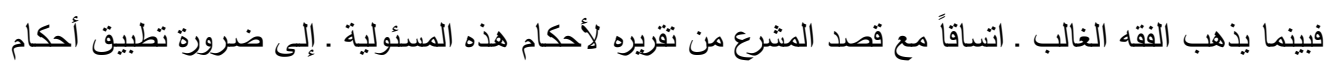

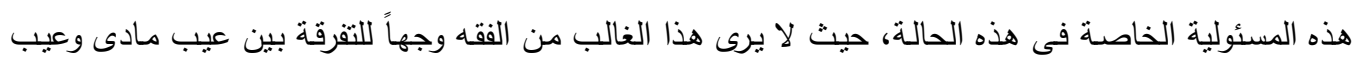
قانونى، طالما كانت النتيجة التى أفضى إليها كل من العيبين واحدة، وهى حدوث التهدم الكلى أو الجزئى بالعقار، فهذه النتيجة بذاتها كافية لتبرير تطبيق أحكام هذه المسئولية الخاصـة طالما لم يستطع المعمارى، مهندساً كان أم مقاولاً، إثبات قيام السبب الأجنبى الذى أدى إلى قيام هذا العيب أو ذاك فى العقار الذى تم تشييده. 


\section{-5 - (لتوصيات}

1- - تعديل نص الفقرة الأولى من المادة 651 مدنى، بما يذهب والفجوة التى أوجدها التطور المتلاحق فى هذا المجال، بين القانون والواقع العملى، وذلك بالنص صراحة على إخضاع كل المهندسين والفنيين الذين أسفر التطبيق المعاصر عن مشاركتهم فى عملية التشييد والبناء، لأحكام هذه المسئولية الخاصة.

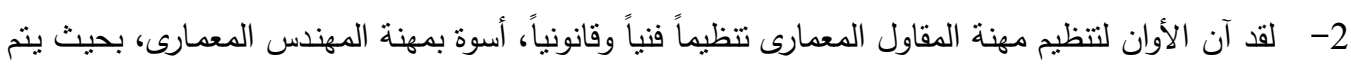
توصيف المقاولين حسب تخصصاتهم، وأهمية الأعمال التى يباشرونها كماً وكيفاً، وبذلك تنظم كيفية مباشرة هذه المهنة، والتأمين من مسئولياتها، وتسهل عملية مراقبتها، وذلك حتى لا يكون مجرد توافر رأس المال .

كما يقول الأستاذ الدكتور/ محمد شكرى سرور ـ هو المؤهل الوحيد لارتياد هذا المجال الخطير (1).

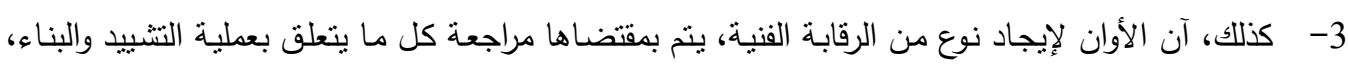

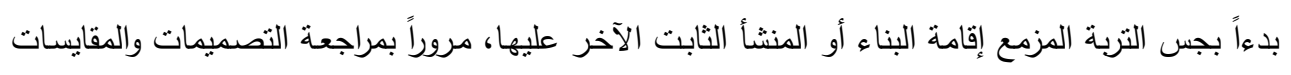

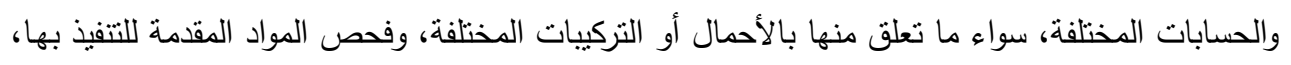
ومتابعة أسلوب التتفيذ أولاً بأول، وهكذا، حتى يتم إنجاز العمل المطلوب، وبذابلك بمكن تدارك الخطأ فور وقوعه، وقبل تفاقم آثاره. ولا بأس فى أن تتولى وزارة الإسكان والمرافق تتظيم هذا النوع من الرقابة الفنية، طبقاً لما تراه محققاً لغرضه،

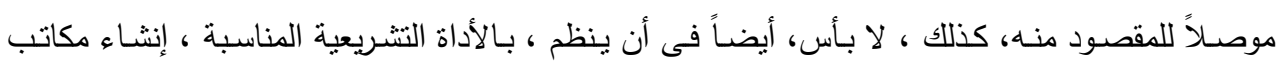

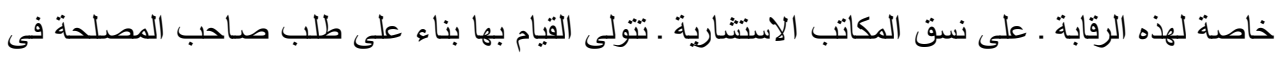
ذلك ، وتكون مسئولة . فى حدود ما يوكل إلبها من مهام ـ طبقاً لأحكام هذه المسئولية الخاصة. 4- النص صراحة على إخضاع المقاول من الباطن . سواء فى العلاقة فيما بينه وبين رب العمل أو فيما بينه

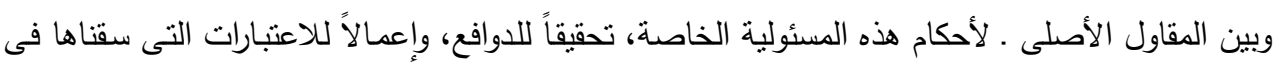
مكانها من الدراسة. 5- كذلك، نـرى أنـه صـار من الضـرورى الآن، أن يخضـع المشـرع المصـرى وبـالنص الصـربح ، لأحكام هذه

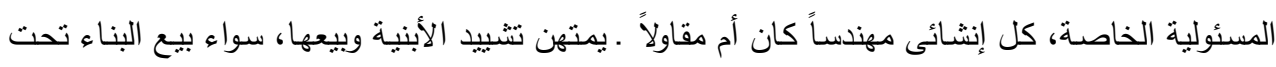
التشييد أو بعد تمـام إنجازه، وسواء وقع البيع عليه فى مجموعـه أو على جزء منه، وكذلك من بمنهنون

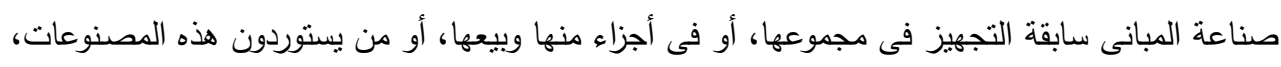

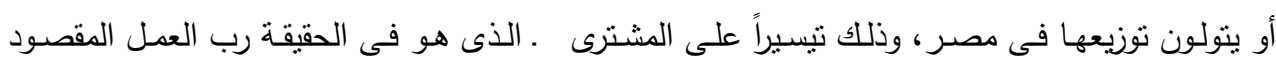
بالحماية ـ فى الحصول على التعويض المناسب لجبر ما لحقه من أضرار، وتنظم السلطة المختصـة بتتظيم وتوجيه أعمال البناء طريقة تحديد التاريخ الذى فيه يكون العقار المشيد قد صار تام الإنجاز صالحاً للنسلم. 6- عديل نص الفقرة الثانية من المادة 651 مدنى، تعديلاً من شانه أن يوسع فى دائرة العيوب التى نتكل نطاقاً موضوعياً لسريان أحكام هذه المسئولية الخاصـة، بحيث يجعلها تشمل، بالإضـافة إلى تلك العيوب المذكورة بها ـ أى التى تهدد البناء أو المنشأ الثابت الآخر ، فى متانته وسلامته ـ العيوب الأخرى التى يكون من شأنها 


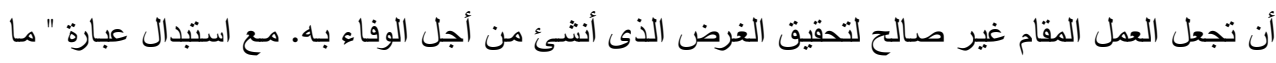

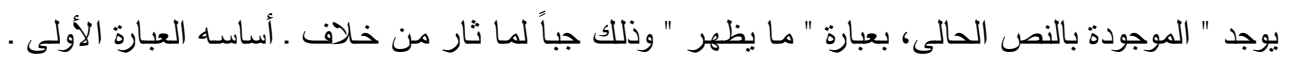

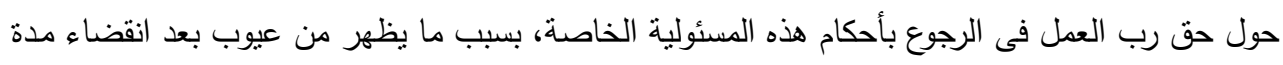

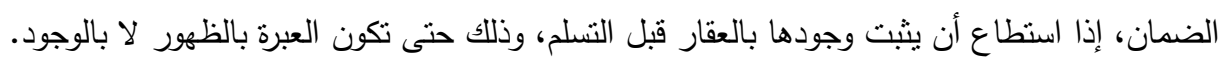

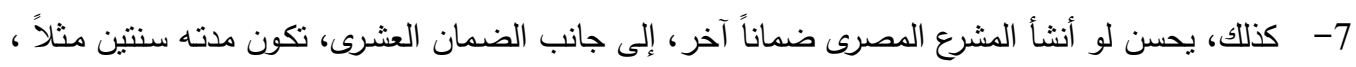

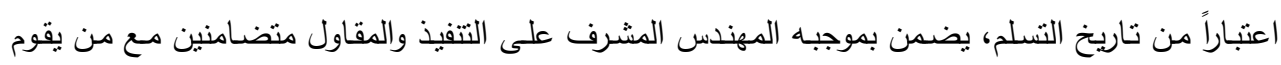

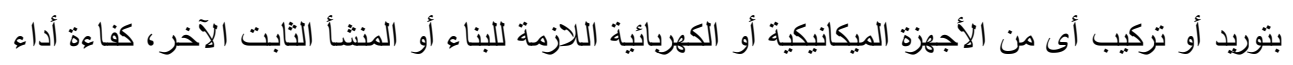
هذه الأجزة لوظيفتها التى خصصت لأدائها فى العقار المشيد.

\section{قائمة المراجع}

1. د. نوفيق حسن فرج : عقد الييع والمقايضة ، مؤسسة الثقافة الجامعية، 1979.

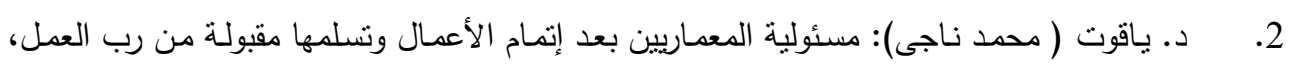
ط1، دار النهضة العربية ، 1984.

3. د. إدوارد لابـان فى رسالته " مسئولية المهندسين المعماريين والتأمين منها" ، المقدمة إلى جامعة باريس والتى نوقثت فى 31 مايو 1978.

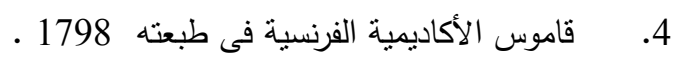
5. نقض مدنى فرنسى فى 14 من ديسمبر 1897 دالوز 1911 ـ 1 ـ 584 6. د. فتحى غيث: قانون المهنس طبعة ، دار المعرفة ، 1960. 7. شكرى سرور : مسئولية المنتج عن الأضـرار التى نسبيها منتجاته الخطرة ، دار الفكر العربى

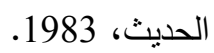

8. عبد الرزاق أحمد السنهورى: الوسبط، ج7، سند 65 فى شرح القانون الدنى المصرى ، ط دار النهضة العربية 1964 .

\section{مجموعات قضائية :}

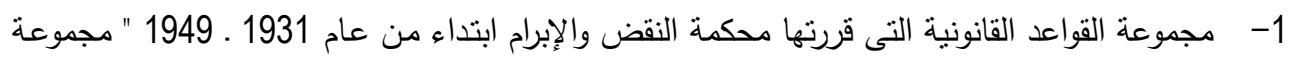

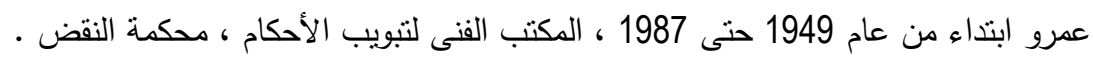
2- مجموعة أحكام النقض الدائرية ـ المدنية والجنائية ، ابتداء من عام 1949 حتى الآن ، إصدار المكتب الفنى لتبويب الأحكام بمحكمة النقض. 